\title{
EVALUATION OF BEST MANAGEMENT PRACTICES FOR SEDIMENT AND NUTRIENT LOSS CONTROL USING SWAT MODEL
}

\author{
Sushil Kumar Himanshu*1,2, Ashish Pandey ${ }^{1}$, Basant Yadav ${ }^{3}$ and Ankit Gupta ${ }^{4}$ \\ ${ }^{1}$ Department of Water Resources Development \& Management, Indian Institute of Technology \\ Roorkee, India \\ ${ }^{2}$ Texas A\&M Agrilife Research, Texas A\&M University System, Vernon, Texas, United States \\ ${ }^{3}$ Cranfield Water Science Institute, Cranfield University, UK \\ ${ }^{4}$ National Remote Sensing Centre, Indian Space Research Organisation, Hyderabad, India
}

\begin{abstract}
The intensive study of an individual watershed is required to develop effective and efficient watershed management plans. Identification of critical erosion-prone areas of the watershed and implementation of best management practices (BMPs) is necessary to control the watershed degradation by reducing the sediment and nutrient losses. The present study evaluates and recommends the BMPs in an agriculture-based Marol watershed $\left(5092 \mathrm{~km}^{2}\right.$ ) of India, using a hydrologic model, Soil and Water Assessment Tool (SWAT). After successful calibration and validation, the model simulated daily/monthly discharge and sediment were found satisfactory throughout the simulation period. The model was then applied with a calibrated set of parameters for evaluating the effectiveness of various management practices for sediment and nutrient loss control. Keeping in mind the existing agricultural practices, socio-economic aspects and geography of the study area, the management practices were focused on four crops (Maize, Rice, Soybeans and Ground nut), three fertilization levels (high, medium and low), four tillage treatments (Field cultivator, Conservation tillage, Zero tillage and Mould board plough), and two conservation operations (Contour farming and Filter strips). The simulated annual average sediment yield from the watershed was found to be $12.2 \mathrm{t}^{-h^{-1}} \mathrm{yr}^{-1}$. The water balance analysis revealed that, the evapotranspiration is predominant over the watershed (approximately $46.3 \%$ of the annual average rainfall). Reduction in sediment yield and nutrient loss was observed with alternate cropping treatments of Groundnut and Soybean, as compared to Paddy and Maize cultivation. Overall, based on simulated results, the field cultivator tillage practice and conservation practices viz., contour
\end{abstract}


farming and filter strips, could be adopted to reduce sediment yield and nutrient losses in the critical sub-watersheds of the study area and in other watersheds with similar hydro-climatic conditions.

Key words: SWAT Model, Sediment yield, Nutrient loss, Tillage, Conservation operations, Best management practices (BMPs)

Corresponding author: "sushilkumarhimanshu@gmail.com; sushil.himanshu@ag.tamu.edu

\section{INTRODUCTION}

Watershed management is an effort to reduce water, soil and nutrient losses from non-point sources (NPS) of the watershed and to ensure sustainable agricultural production (Tripathi et al., 2005; Tuppad et al., 2010; Liu et al., 2016; Wang et al., 2018). NPS pollution has increasingly become a threat to water quality and aquatic ecosystem restoration (Conley et al., 2009; Dong et al., 2018). The main sources of the NPS pollutants are soil erosion and pollutant loads arising from agriculturerelated activities (Humenik et al., 1987; Duchemin and Hogue, 2009; Yang and Best, 2015). By adopting sustainable agricultural management practices, land degradation due to soil erosion and pollutant loads from agricultural watersheds can be controlled. Every year about $0.3-0.8 \%$ of the world's cultivated land is affected by excessive land degradation, making the soil unsuited for agricultural production (den Biggelaar et al. 2004a). According to den Biggelaar et al. (2004b), there will be an additional requirement of 200 million ha of crop area to feed the increasing population over the next 30 years. Moreover, in agricultural fields, over-fertilization causes deterioration of fresh water resources due to high levels of nitrogen and phosphorus leaching, while some of the dissolved nitrogen and phosphorous also leaves in runoff. It was outlined that about $45 \%$ of phosphorus fertilizer and only $30-50 \%$ of the applied nitrogen fertilizer is taken up by crops (Tilman et al., 2002). Pradhan et al. (2015) reported that a significant amount of the applied nitrogen and phosphorus is lost from agricultural fields. Therefore, a balanced management approach is needed to prevent soil and nutrient loss, and to protect productive farmland from further 
degradation. Implementation of a suitable and practicable management plan for an individual watershed is necessary to control the transport and delivery of NPS pollutants to waterbodies. This kind of management approach will also be useful for other watersheds, with similar hydro-climatic conditions.

In order to implement management programs, prioritization of sub-watersheds is mandatory, so that the critical sub-watersheds can be taken up primarily for treatment considering technical or financial constraints (Prasad et al., 1997; Tripathi et al., 2003; Pandey et al., 2007; Rocha et al., 2012; Gopinath et al., 2016; Lamba et al., 2016). Physically based hydrologic models backed with geographic information systems and remote sensing techniques become popular in identification of the most critical erosion-prone areas of a watershed and selection of a suitable management strategy. Among various physically based models, the SWAT model has been employed under several agro-climatic regimes for different hydrologic applications. The BMPs could be evaluated for critical erosion-prone areas using the SWAT model and recommended for better conservation of soil and moisture (Arnold et al., 1996; Srinivasan et al., 1998).

The SWAT is a physically-based, semi-distributed hydrologic model, and capable of continuous simulation over long time periods (Arnold et al., 1998; Arnold and Fohrer, 2005; Garg et al., 2012; Pandey et al., 2016), developed by the USDA Agricultural Research Service (ARS) to predict the impact of land management practices on hydrology, contaminant and sediment transport in complex, large watersheds (Borah and Bera, 2003). The SWAT hydrologic model has been evaluated by several researchers globally for runoff (Akiner and Akkoyunlu, 2012; Murty et al., 2014; Pandey et al., 2015; Asl-Rousta et al., 2018; Dhami et al., 2018), sediment load (Xu et al., 2009; Oeurng et al., 2011; Qiu et al., 2012; Himanshu et al., 2017, 2018; Brighenti et al., 2019) and 
nutrient (Wang et al., 2014; Gildow et al., 2016; Qiu et al., 2018; Uribe et al., 2018) simulation, who reported satisfactory model performance.

BMPs are generally recognized as an effective control measure for agricultural non-point sources of sediment and nutrients (Tripathi et al., 2005; Lam et al., 2011; Jang et al., 2017). The SWAT model is a tool that predicts the impact of BMPs on runoff, sediment and agricultural chemical yields (nutrient loss) in complex watersheds (Ullrich and Volk, 2009; Arnold and Fohrer, 2005, Murty et al., 2014). Site-specific conditions and dimensions of agricultural BMPs as well as the tillage practices can be incorporated in the SWAT model which is often beyond the capacity of most other watershed models (Xie et al., 2015). The effectiveness of BMPs using the SWAT model has been explored by researchers worldwide (McGregor et al., 1999; Pandey et al., 2005, 2009b; Betrie et al., 2011; Zhang and Zhang, 2011; Bossa et al., 2012; Strauch et al., 2013; Rocha et al., 2015; Pare et al., 2015; Lampurlanes et al., 2016; Maharjan et al., 2016; Strehmel et al., 2016; Her et al., 2017; Noor et al., 2017; Merriman et al., 2018; Ni and Parajuli, 2018; Qiu et al., 2018; Wang et al., 2018). These studies revealed that the SWAT model has the ability to evaluate BMPs to reduce NPS pollution (sediment and nutrient load) depending on watershed characteristics, and the type and combinations of applied BMPs. Wei et al., 2018 conducted a study to analyze the influence of BMPs in irrigated watersheds of the Arkansas River valley in southeastern Colorado, which shows that the consideration of individual cultivated fields is necessary to fully capture the hydrologic processes and magnitude of losses. Further, an enhanced paddy simulation module integrated with SWAT (namely SWAT-Paddy) has been applied to an agricultural watershed in Japan, which suggest that the model can simulate management processes realistically in paddydominant agricultural watersheds (Tsuchiya et al., 2018). Likewise, other crop specific modules can also be integrated with SWAT to explicitly understand the management processes and control 
over losses. Implementation of agricultural BMPs is influenced by a balance of desired economic feasibility and environmental outcomes. Many studies have been conducted to couple multiobjective optimization methods to the SWAT model to optimize the selection and placement of BMPs from both economic and environmental points of view (Chiang et al., 2014; Herman et al., 2015; Pyo et al., 2017). However, in India, very few studies were conducted using the hydrologic and water quality models to evaluate the effects of BMPs on nutrient losses from a watershed (Tripathi et al., 2005; Behera and Panda, 2006; Tripathi et al., 2013).

The literature reveals that rigorous implementation of the SWAT model is required to develop watershed management plans under various hydro-climatic regions. Considering to the aforementioned, a calibrated and validated SWAT model has been adopted for erosion-based prioritization and also for evaluation of BMPs for sediment and nutrient loss control over the agriculture-based Marol watershed of India. Primarily, evaluation of the SWAT model has been carried out for analyzing the spatial distribution of water balance components across the watershed. Soil erosion status in the Marol watershed was also accomplished to provide the priority of subwatersheds for soil conservation measures. The critical sub-watersheds have been identified based on the SWAT simulated annual average sediment yields for the years 1999 to 2011 (Singh et al., 1992; Dabral and Pandey, 2007; Pandey et al., 2009a, 2009b; Niraula et al., 2013). The critical subwatersheds which are more prone to soil erosion were also examined for nutrient losses. Further, the SWAT model was employed for assessing the effectiveness of various management strategies in reducing sediment and nutrient loads considering different crops, tillage implements, fertilizer applications and management operations. In this study, calibration and sensitivity analysis for nutrients were not carried out, due to unavailability of observed dataset, which could be a limitation of this study and may have some uncertainties involved in the nutrient simulation results. 


\section{Materials and Methods}

\subsection{Study Area}

The study area i.e., the Marol watershed, is part of the Krishna River basin, situated along the subtributary Vardha River of the tributary Tungabhadra River. Figure 1 shows location, land use/land cover and soil map of the study area. The study area lies between longitude $74^{\circ} 48^{\prime} 30^{\prime \prime}$ E to $75^{\circ} 36^{\prime} 38^{\prime \prime}$ E and latitude $14^{\circ} 05^{\prime} 18^{\prime \prime} \mathrm{N}$ to $15^{\circ} 07^{\prime} 48^{\prime \prime} \mathrm{N}$ with an elevation of 340 to $848 \mathrm{~m}$ above sea level. The total watershed area is $5092 \mathrm{~km}^{2}$. The mean slope of the watershed ranges from 0 to $8.9 \%$ as major part is gently undulating plain and the maximum land slope of the watershed goes up to $31 \%$ due to the presence of some hilly areas on the western most part. The temperature of the study area varies from $16^{\circ} \mathrm{C}$ to $38^{\circ} \mathrm{C}$. The average annual rainfall of the watershed is $1624 \mathrm{~mm}$, out of which more than $75 \%$ of rainfall occurs during the monsoon season (June to October). Absence of any large storage structures, availability of observed hydro-meteorological datasets, and heterogeneous land use makes this watershed a favorable one for carrying out this study.

Figure 1: Study area description maps a) Location map, b) Land use/ land cover map and c) Soil map

\subsection{Datasets used}

Relevant information of all the datasets utilized in the present study has been provided in Table $\mathbf{1 .}$ The improved daily gauge-based gridded precipitation data prepared by the India Meteorological Department (IMD) at a spatial resolution of $0.25^{\circ} \times 0.25^{\circ}$ (approx. $27.5 \mathrm{~km} \times 27.5 \mathrm{~km}$ ) grid (Pai et al., 2014, 2015) were used as standard reference data set for evaluation. The study area is covered under fifteen grid points of precipitation. IMD used the Shepard interpolation method (Shepard, 1968), a simplest form of inverse distance weighted interpolation scheme to interpolate the station point observations into a regular grid after applying severe quality-checks. In this method, 
interpolated values were computed from a weighted sum of the observations. The daily temperature data available at a coarser resolution of $1^{\circ} \times 1^{\circ}$ (approx. $\left.110 \mathrm{~km} \times 110 \mathrm{~km}\right)$ grid prepared by the IMD were used in the present study (Srivastava et al., 2009). Other meteorological data like relative humidity, wind speed and solar radiation were obtained from the Global Weather Database for SWAT (Dile and Srinivasan, 2014). These datasets are based on the hourly forecast from National Centers for Environmental Prediction (NCEP) Climate Forecast System Reanalysis (CFSR) data products (Saha et al., 2010). Except for temperature, all meteorological datasets used are at $0.25^{\circ} \times$ $0.25^{\circ}$ (approx. $27.5 \mathrm{~km} \times 27.5 \mathrm{~km}$ ) spatial resolution.

The daily stream discharge and suspended sediment load datasets (1998 to 2011) for Marol gauge

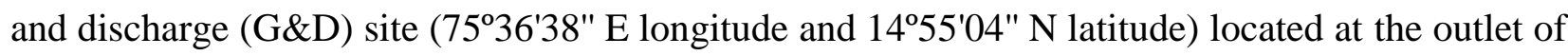
the Varadha River were obtained from the India Water Resources Information System (WRIS) WebGIS portal maintained by the Central Water Commission (CWC), Government of India. However, continuous stream discharge and suspended sediment load data for the years 2005 to 2007 were not available, hence, not considered for simulation in this study. These data are available only for the monsoon period (June to October), therefore, only monsoon data have been used as reference data for evaluation of the SWAT model.

The freely available ASTER Digital Elevation Model (DEM) with 30-m spatial resolution has been used for delineating the watershed and stream networks. The minimum, mean and maximum elevations of the study area were found to be $340 \mathrm{~m}, 588 \mathrm{~m}$ and $848 \mathrm{~m}$ respectively. The slope map was reclassified into 4 slopes viz., 0 to $2.8 \%, 2.8$ to $6.3 \%, 6.3$ to $14.2 \%$ and more than $14.2 \%$. The soil data utilized in the present study was obtained from the "National Atlas and Thematic Mapping Organization, Department of Science and Technology, Government of India" (Shivaprasad et al., 1998). Seven soil types are prevalent in the study area whose spatial distribution is presented in 
Figure 1. The land use/land cover map of the study area was obtained from the "National Remote Sensing Centre (NRSC) Hyderabad, Government of India”, and 10 land use/land cover classes were identified within the study area (Figure 1). The map was prepared under the project "National Land Use/ Land Cover Mapping (Second Cycle)" on 1:50,000 scale using temporal Resourcesat-2 terrain corrected multi-spectral linear imaging self-scanning sensor-III (LISS-III) remotely sensed data of 2011-12 (NRSC, 2014).

Table 1: Datasets used in the present study

\subsection{Model Evaluation Statistics}

The statistical indices viz., percent bias (PBIAS), correlation coefficient (CC), ratio of the root mean square error to the standard deviation of measured data (RSR), Nash-Sutcliffe efficiency (NSE) and Index of agreement (d) have been used for performance evaluation of the SWAT model (Moriasi et al., 2007; Niraula et al., 2011).

PBIAS shows the average tendency of the simulated data to be smaller or larger than their observed counterparts and ranges from $-\infty$ and $+\infty$ (Gupta et al., 1999). CC measures the direction and strength of a linear relationship between observed and estimated data. The value of CC ranges from -1.0 to $+1.0,-$ and + signs have been used for negative and positive linear correlations, respectively. RSR standardizes the root mean square error using observations standard deviation. RSR ranges from the optimal value of 0 to a large positive value. NSE shows how well the plot of simulated and observed data fits the 1:1 line and ranges from $-\infty$ and 1.0. The $\mathrm{d}$ is a standard measure of the degree of model prediction error and ranges between 0 and 1.0.

$$
P B I A S=\left[\frac{\sum_{i=1}^{n}\left(Y_{i}^{o b s}-Y_{i}^{s i m}\right) *(100)}{\sum_{i=1}^{n} Y_{i}^{o b s}}\right]
$$




$$
\begin{aligned}
& C C=\left[\frac{\sum_{\mathrm{i}=1}^{\mathrm{n}}\left(\mathrm{Y}_{\mathrm{i}}^{\text {obs }}-\overline{\mathrm{Y}^{\text {obs }}}\right)\left(\mathrm{Y}_{\mathrm{i}}^{\text {sim }}-\overline{\mathrm{Y}^{\text {sIm }}}\right)}{\sqrt{\sum_{\mathrm{i}=1}^{\mathrm{n}}\left(\mathrm{Y}_{\mathrm{i}}^{\text {obs }}-\overline{\mathrm{Y}^{\text {obs }}}\right)^{2}} \sqrt{\sum_{\mathrm{i}=1}^{\mathrm{n}}\left(\mathrm{Y}_{\mathrm{i}}^{\text {sim }}-\overline{\mathrm{Y}^{\text {sIm }}}\right)^{2}}}\right] \\
& R S R=\left[\frac{\sqrt{\sum_{i=1}^{n}\left(Y_{i}^{\text {obs }}-Y_{i}^{\text {sim }}\right)^{2}}}{\sqrt{\sum_{i=1}^{n}\left(Y_{i}^{\text {obs }}-\overline{\mathrm{Y}^{\mathrm{obs}}}\right)^{2}}}\right] \\
& N S E=1-\left[\frac{\sum_{i=1}^{n}\left(Y_{i}^{\text {obs }}-Y_{i}^{\text {sim }}\right)^{2}}{\sum_{i=1}^{n}\left(Y_{i}^{\text {obs }}-\overline{\mathrm{Yobs}^{\mathrm{obs}}}\right)^{2}}\right] \\
& d=1-\frac{\sum_{i=1}^{n}\left(Y_{i}^{o b s}-Y_{i}^{s i m}\right)^{2}}{\sum_{i=1}^{n}\left(\left|Y_{i}^{s i m}-\overline{Y^{o b s}}\right|+\left|Y_{i}^{o b s}-\overline{Y^{o b s}}\right|\right)^{2}}
\end{aligned}
$$

$\mathrm{Y}_{\mathrm{i}}^{\mathrm{obs}}, \mathrm{Y}_{\mathrm{i}}^{\mathrm{sim}}, \overline{\mathrm{Y}^{\text {obs }}}$ and $\overline{\mathrm{Y}^{\text {sim }}}$ are the observed, simulated, average observed and average simulated values in respective time steps $\mathrm{i}$, and $\mathrm{n}$ is the number of observations

\subsection{SWAT Model Setup}

The ArcSWAT interface has been used to set-up and run the model on a daily and monthly timescale for the period 1998-2011. Spatial datasets (DEM, land use map, soil map etc.) required for the SWAT model setup were projected into the same co-ordinate system (WGS 1984) using the ArcGIS interface. The land use, soil and slope distribution over the Marol watershed are provided in Table 2. The details of land use and soil data was prepared and enlisted in the look up table, which was not included in the default SWAT database. In this study, the Marol watershed was divided into 31 sub-watersheds, based on the user-defined threshold area of 8000 ha along with location of the gauging sites, and outlet points to facilitate precise hydrologic analysis and model simulation. The watershed was then divided into 647 HRUs representing homogeneous hydrological regions defined with unique land use, soil and slope (threshold value of $1 \%$ each). The selection of threshold values was based on the desired stream network density, and the connectivity 
of drainage network to water reservoirs that mainly affects river channel flow and the outflow at the gauging site. The hydrologic evaluation of the SWAT model was carried out at the HRU level in daily time steps and the outcomes were aggregated to give output at the sub-watershed scale.

Table 2: Detailed land use, soil and slope distribution over the Marol watershed

\subsection{Sensitivity and Uncertainty Analysis}

The sensitivity and uncertainty analyses were carried out using the SUFI-2 algorithm of the SWATCUP program (Abbaspour et al., 2007). A total of 17 sensitive parameters were considered separately for discharge and sediment (Table 3). The analysis was carried out on a daily time step in order to accurately preserve the hydrologic characteristics of the watershed accurately. Calibration of the model at monthly/annual time step does not guarantee a good performance at daily time steps (Sudheer et al., 2007). Since the model uses the daily flow dataset to simulate model outputs including sediment and nutrients, it is important that the model-predicted dataset at daily time-scale accurately mimics the actual watershed processes. The sensitivity analysis revealed that discharge is most sensitive to CH_N2 (Manning's ' $n$ ' value for the main channel) followed by CH_K2 (Effective hydraulic conductivity in main channel alluvium), whereas sediment is most sensitive to OV_N (Manning's 'n' value for overland flow) followed by USLE_P (USLE equation support practices factor).

Table 3: Discharge and sediment load sensitivity order of the SWAT model parameters for the Marol Watershed

\subsection{Effective management of the critical sub-watersheds}

To control the sediment and nutrient loss from the critical sub-watersheds, an effort has been made to identify the BMPs for the critical sub-watersheds considering different management operations. Major parts of the study area are under agronomic practices. Therefore, crop based agronomic 
measures and management operations were only considered for treatment options in the present study. Based on the available field data and existing agricultural practices, various treatment options were selected for evaluating the BMPs. In this study, different operations were simulated in order to develop an appropriate management strategy suited to the farmers of the Marol watershed. Four crops, i.e., rice, maize, soybean and ground nut at three fertilization levels of $\mathrm{N}: \mathrm{P}(\mathrm{kg} / \mathrm{ha})(\mathrm{high}$, medium and low) were considered. Four tillage practices, i.e., zero tillage (T1), conservation tillage (T2), field cultivator (T3) and mould board plough (T4), and two management operations, i.e., contour farming (CF) and filter strip (FS) were also considered in the present study for evaluation of the BMPs. In the present study, the effects of agronomic measures, tillage practices and management operations on sediment yield and nutrient loss were studied.

\subsubsection{Tillage implements for effective management}

The conventional tillage practice mostly country plough is used by the farmers of the Marol watershed. The practice of using mould board plough, zero tillage, conservation tillage and field cultivation is relatively less in the watershed area due to farmer's poor knowledge of improved agricultural implements and financial constraints. The tillage treatments were selected based on previous studies (Triphati et al., 2005; Behera and Panda, 2006; Pandey et al., 2009a, 2009b) undertaken in the different Indian watersheds for evaluation of the best management practices. The tillage treatments along with their respective mixing efficiencies and tillage depths (in $\mathrm{mm}$ ) as suggested by Neitsch et al. (2011) are presented in Table 4. The mixing efficiency and the tillage depth determine the fraction of the soil layer that is mixed by a tillage operation (Triphati et al., 2005).

Table 4: Tillage treatments considered for effective management 


\subsubsection{Crop-fertilization evaluation for best management practices}

In the present study, four crops i.e., Rice (Oryza sativa), Maize (Zea mays), Groundnut (Archis hypogaea) and Soybean (Glycine max) were considered for developing management scenarios. Rice is the predominant crop of the Marol watershed, grown with low fertilizer doses $(25 \mathrm{~kg} \mathrm{~N} / \mathrm{ha}$ and $15 \mathrm{~kg} \mathrm{P} / \mathrm{ha}$ ) and high seeding rate (140-180 $\left.\mathrm{kg} \mathrm{ha}^{-1}\right)$, normally sown during the months of JuneJuly and harvested during the months of September-October. Maize is generally grown in the steeply-sloped lands along the river mainly during monsoon season (June to October). Groundnut is grown in few locations by some of the farmers in the steeply-sloped lands along the river of the Marol watershed. As a cash crop Soybean could be suitable as per prevailing agro-climatic conditions of the watershed, therefore, considered in this study. The crop schedule suggested by Prasad (2002) and Singh et al. (2003) has been adopted in this study.

In terms of phosphorus and nitrogen availability, soils in the study area are mostly low in fertility. Soils are mostly acidic in nature; therefore, phosphorous availability is limited due to fixation in acidic soils. Nitrogen is available in the soil mainly in the form of nitrate $\left(\mathrm{NO}_{3}\right)$. Therefore, management practices with different fertilization level for already described four crops were evaluated in all the critical sub-watersheds to identify suitable management practices to maintain productivity and soil fertility on a sustainable basis. In general, farmers of this region use an amount of fertilizer that is lower than the recommended dose. The existing level of fertilizer was categorized as low fertilization level. Fertilization levels for different crops were considered based on studies undertaken by previous researchers (Triphati et al., 2005; Behera and Panda, 2006; Pandey et al., 2009a, 2009b) in the different Indian watersheds and are presented in Table 5.

Table 5: Fertilization level with values of $\mathrm{N}: \mathrm{P}(\mathrm{kg} / \mathrm{ha})$ for various crops considered for management 


\subsubsection{Conservation management operations for best management practices}

The SWAT model offers eight options for management operations viz., a) Terracing, b) Tile drainage, c) Contouring, d) Filter strips, e) Strip cropping, f) Fire, g) Grassed water ways, h) Plant parameter update, i) Residue management, and j) Generic conservation practices, to control sediment and nutrient loss from the watershed. Conservation management operations are rarely practiced in the study area. Keeping in mind the socio-economic aspects and geography of the study area, a non-recurring management practice, the contour farming and filter strips were considered in all the HRUs of critical sub-watersheds. Contour farming practices consist of performing the field operations (viz., plowing, planting, cultivating, and harvesting) along the contour which intercepts runoff and reduces the development of rills. When the land slope ranges from $3 \%$ to $8 \%$, contour farming can effectively prevent soil erosion ( $\mathrm{Ng}$ et al., 2008; Guto et al., 2011). Filter strips are densely vegetated areas located between surface water bodies (i.e., lakes and streams) and cropland/grazing land/forestland/disturbed land (Srivastava et al., 1996). Filter strips reduce sediment and nutrients, however, their effect on surface runoff is insignificant in the SWAT water balance (Ullrich and Volk, 2009). This management operation was scheduled at the beginning of the simulation period. The ratio of field area and filter strip area was kept at the default value of 40 . The width of the filter strip was taken as $5 \mathrm{~m}$.

\section{RESULTS AND DISCUSSIONS}

\subsection{Evaluation of the SWAT model for discharge and sediment}

The SWAT model has been evaluated on a daily and monthly basis using observed discharge and suspended sediment load data for the Varadha River at the Marol G \& D site. The total available observed data series were divided into two parts, 1998-2004 for calibration and 2008-2011 for validation, out of which the year 1998 was used as a model warm-up period. The performance 
evaluation of the SWAT model on the basis of daily and monthly discharge and sediment is shown in Table 6. The observed and simulated daily and monthly discharges for the calibration and validation periods are presented in Figures $\mathbf{2}$ and 3, respectively. Similarly, simulated and observed daily and monthly sediment loads for the calibration and validation periods are shown in Figures 4 and 5, respectively. Further, the scatter plots of observed versus SWAT simulated daily discharge, monthly discharge, daily sediment load and monthly sediment load are presented in Figures 6, 7, $\mathbf{8}$ and $\mathbf{9}$, respectively to support the preceding results by visual inspection. The graphical as well as statistical results show that the observed and simulated discharge and sediment yield closely match during the simulation period, except for some high flow events which were mostly underestimated. This may be partially because the curve number technique used by the SWAT model could not accurately predict runoff for a day that experienced several storms (Kim and Lee, 2008). The curve number technique defines a rainfall event as the sum of total rainfall during one day, which might have caused the underestimation (Choi et al. 2002). However, most of the hydrologic models do not simulate extreme events very well. The selection of the SWAT hydrologic model for long term simulation could imply a limitation of this study. Simulation using monthly discharge data has performed better than simulation using daily discharge data. This reveals the fact that in comparison to short term or single storm simulation, the SWAT model performs better for long term simulation (Borah et al., 2007).

Table 6: Performance evaluation of the SWAT model

Figure 2: Comparison of the observed and SWAT simulated discharge for daily calibration (1999-2004) and validation (2008-2011) at the watershed outlet

Figure 3: Comparison of the observed and SWAT simulated discharge for monthly calibration (1999-2004) and validation (2008-2011) at the watershed outlet 
Figure 4: Comparison of the observed and SWAT simulated sediment load for daily calibration (1999-2004) and validation (2008-2011) at the watershed outlet

Figure 5: Comparison of the observed and SWAT simulated sediment load for monthly calibration (1999-2004) and validation (2008-2011) at the watershed outlet

Figure 6: Observed versus simulated discharge for daily a) calibration and b) validation

Figure 7: Observed versus simulated discharge for monthly a) calibration and b) validation

Figure 8: Observed versus simulated sediment load for daily a) calibration and b) validation

Figure 9: Observed versus simulated sediment load for monthly a) calibration and b) validation For runoff simulation, the obtained NSE values of 0.82 and 0.83 for daily and monthly calibrations, respectively; 0.74 and 0.78 for daily and monthly validations, respectively, showed very good simulations (Moriasi et al., 2007). However, PBIAS values of -1.58 and -12.46 for daily and monthly calibrations, respectively; 10.25 and 7.77 for daily and monthly validations, respectively (Table 6), indicated that on the average the SWAT model underestimated discharge by $1.58 \%$ and $12.46 \%$ during daily and monthly calibration, respectively, however overestimated by $10.25 \%$ and 7.77\% during daily and monthly validation, respectively (Figures 2 and 3). Similarly, other performance evaluation criteria showed a very good agreement between observed and simulated hydrographs on both daily and monthly time scales indicating very good performance of the SWAT with IMD gauge precipitation inputs.

Sediment load simulation gave the similar trend like runoff. The NSE values of 0.69 and 0.73 for daily and monthly calibration, respectively; 0.63 and 0.71 for daily and monthly validations, respectively, showed very good performance (Moriasi et al., 2007). However, PBIAS values of 25.16 and -22.69 for daily and monthly calibrations, respectively; 26.24 and 16.59 for daily and monthly validations, respectively (Table 6), indicated that on the average the SWAT model underestimated sediment load by $25.16 \%$ and $22.69 \%$ during daily and monthly calibration, 
respectively, however overestimated by $26.24 \%$ and $16.59 \%$ during daily and monthly validation (Figures 4 and 5), respectively. Similarly, other performance statistics indicate very good performance of the SWAT model for sediment load simulation with IMD Gauge precipitation inputs.

The SWAT model was calibrated and validated only at the watershed outlet where observed discharge and sediment load data were available. Though the model calibration performance seems quite good for the calibrated gauging station, multi-site evaluation of the SWAT model should be carried out to achieve a better representation of the physical parameters and to improve the model's predictions. However, due to the limitation of availability of observed data at the watershed outlet only, single site calibration was carried out in this study.

\subsection{Evaluation of the SWAT model for the water balance of the Marol watershed}

The average annual water balance over the simulation period (1999-2011) has been estimated for 31 sub-watersheds in total using the SWAT model (Figure 10 and Table 7). Evapo-transpiration has been found predominant and accounts for approximately $46.3 \%$ of the annual average precipitation $(1616.9 \mathrm{~mm})$ falling over the area. Further, as shown in Table 7, about $42.0 \%$ of the annual average precipitation leaves the watershed as surface run-off. It was observed that almost all the sub-watersheds, converts about $25 \%$ of annual precipitation into surface run-off, indicating the need of implementing suitable soil and water management programs to decrease the run-off volume by increasing in-watershed utilization of water in turn minimizing soil erosion.

The monthly break up of average annual water balance (in $\mathrm{mm}$ ) over the entire Marol watershed is presented in Figure 11 and Table 8. From Table 8, it has been inferred that the monthly evapotranspiration in dry months is higher than total precipitation during that month. This is because the process of evapo-transpiration is continuous which occur throughout day and night at variable rates 
whether there is precipitation or not, as the water for evapo-transpiration comes from near surface soil moisture. The rate of evapo-transpiration also depends on the root zone depth and hence can extract water from the deeper soil layers. Moreover, the SWAT model is a continuous model and accounts for change in soil moisture content, which facilitates the consideration of the previous day's soil moisture content too. Therefore, it is possible that in a specific month total precipitation is less than the total evapo-transpiration. However, the annual evapo-transpiration is less than annual precipitation. The evapo-transpiration was found to be highest in the month of April (117.3 $\mathrm{mm})$ and lowest in the month of January $(9.1 \mathrm{~mm})$. On the average, about $96 \%$ of the total surface flow occurs during the five monsoon months (June to October) compared to about $91 \%$ of annual rainfall occurring during the corresponding months. This reveals that, implantation of suitable BMPs demands to reduction of the surface runoff from agricultural areas controlling the sediment and nutrient losses.

Table 7: Sub-watershed wise annual average water balance in the study area

Figure 10: Sub-watershed wise annual average water balance components

Table 8: Monthly break up of average annual water balance

Figure 11: Monthly average values of water balance components

\subsection{Soil erosion status in the Marol watershed}

In this study, annual average sediment yield from the sub-watersheds not only provides the basis for identification and prioritization of the critical sub-watersheds, but also helps for the planning of agricultural and structural management of the watershed. It could be quite appropriate to utilize the average of the model outputs (sediment yield) from different sub-watersheds for identification and prioritization of critical sub-watersheds, since the simulated sediment yield for the entire simulation period are in close agreement with the observed values. With this in view, the simulated sediment 
yields employing IMD gauge data benchmarked SWAT model for all the thirty one sub-watersheds of Marol for the entire ten years of simulation and the average value for each sub-watershed were determined and are presented in Table 9.

The annual average sediment yield $\left(\mathrm{t}^{-} \mathrm{h}^{-1} \mathrm{yr}^{-1}\right)$ from each sub-watersheds were regrouped into different priority scales according to the guidelines suggested by Singh (1995) for Indian conditions: slight $(<5)$, moderate (5-10), high $(10-20)$, very high $(20-40)$, severe $(40-80)$ and very severe (>80) erosion classes as presented in Table 10. The majority of sub-watersheds (69.7\%) are falling under slight erosion class. It can be seen from Table 10, that high and very high erosion prone areas falling under the watershed are about $24.9 \%$, while severe erosion prone area is about $5.5 \%$. No sub-watershed is falling under moderate and very severe erosion class. The majority of HRUs correspond to barren land and agricultural land use type in the sub-watersheds which are falling under the severe erosion class. It has been observed that sub-watersheds 7, 8, 20 and 22 are falling under severe soil erosion prone areas for which immediate attention is required (Table 10). Sub-watershed 22 has been found most severe with an average annual sediment yield of 69.8 t.ha $^{-}$ ${ }^{1} \mathrm{yr}^{-1}$ (Table 9). Among the slight erosion class category, the majority of HRUs belong to land cover type of forest or water body with different combinations of soil and slope classes. The subwatershed wise annual average sediment yield $\left(\mathrm{t} \mathrm{ha}^{-1} \mathrm{yr}^{-1}\right)$ map is presented in Figure 12. The higher rate of erosion might be ascribed to the faulty method of cultivation practices prevalent in the study area, the higher slope in some parts of the area and also the barren land contributing more sediment load. The average annual sediment yield of the watershed was found to be 12.2 t.ha $^{-1} \mathrm{yr}^{-1}$, which is high, and if not managed properly it will tend to increase in the future because of ongoing deforestation to provide housing and agricultural land to cope up with the rising population. This 
study provides prioritization of sub-watersheds for soil conservation measures. The results were further implemented for evaluating BMPs in the critical sub-watersheds.

Table 9: Average annual sediment yield in the years for identification of critical sub-watersheds

Table 10: Area under different soil erosion classes in the Marol watershed

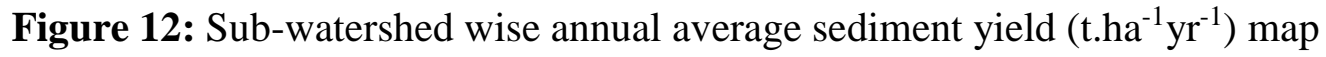

\subsection{Identification and effective management of critical sub-watersheds}

A wide variation in sediment yields were observed in various sub-watersheds in different years (Table 9). Maximum sediment yield in the most critical sub-watershed was found to be $323.3 \mathrm{t} \mathrm{ha}^{-}$ 1 in the year 2011 when the observed precipitation was highest $(2222.4 \mathrm{~mm})$. Similarly, the minimum sediment yield was observed in the range of 0 to $3 \mathrm{tha}^{-1}$ in the year 2003 when the observed precipitation was at minimum $(1030.8 \mathrm{~mm})$. It can be seen from Table 9 that the subwatershed numbers SW-22, SW-20, SW-8, SW-7, SW-6, SW-25, SW-18, SW-17, SW-13, SW-27 and SW-3 are belonging to high, very high and severe erosion classes, and are only considered for evaluating BMPs. The maximum sediment yield in all the years of study was observed from subwatershed 22 (Table 9). This may be due to the steep slope of up to $59.1 \%$ at many locations in the sub-watershed with an average of $3.2 \%$ and undulating topography. Low sediment yield in the majority of sub-watersheds was observed due to the cultivation of rice by bunding and the flat topography with the gentle average slopes. Since the study watershed is already treated with some soil conservation measures, some portions of the watershed might have got stabilized.

Similarly, nutrient losses have also been simulated using the SWAT model for the entire thirty one sub-watersheds of the Marol watershed. The simulated results showed that the nutrient losses were within the tolerable limit in most of the sub-watersheds (EPA, 1976; Tim et al., 1992). Nutrient 
losses were found proportional to the loss of sediment from the sub-watersheds. Therefore, the above mentioned 11 sub-watersheds were considered for examining the effect of implementation of BMPs on sediment and nutrient loss in the sequential order of priority. Other sub-watersheds were not considered because they do not yield sediment higher than slight/ moderate erosion classes.

Results showed that nutrient losses usually did not exceed the tolerable limit in different subwatersheds, however, in all critical sub-watersheds sediment yield was higher than the tolerable limit (Mannering, 1981). It has been assumed that agronomic measures including operation management will be sufficient to control the sediment loss. Although, the nutrient losses were within the tolerable limit, the effect of BMPs on nutrient losses was also considered, so that it can be monitored in the future. Based on the higher sediment yield, critical sub-watersheds were identified and attempt was made to use the SWAT model to evaluate the effects of tillage treatment and change in cropping pattern on sediment yield and nutrient loss. Based on the available field data and existing practices of cultivation, various alternative treatments and operation managements were considered for evaluating the BMPs. Overall, the study revealed that the SWAT model could be used successfully for the evaluation and implementation of BMPs.

\subsection{Tillage treatments for effective management}

The effects of tillage treatments on sediment and nutrient losses for the rice crop were evaluated for all the critical sub-watersheds and are presented in Figure 13. Tillage with mould board plough yielded about $9.5 \%$ more sediment as compared to conventional tillage (country plough) practice. Although, other tillage treatments viz., field cultivator, conservation tillage and zero tillage practices yielded about $9.0 \%, 6.8 \%$ and $5.4 \%$ less sediment, respectively, as compared to conventional tillage. This demonstrates that the tillage with higher mixing efficiency generated 
higher sediment yield. The mixing efficiency plays an important role in mixing of residues and fertilizer during the initial crop growth stage, and the soil erosion was affected by the mixing efficiency since it is directly related to the residue present on the soil surface (Tripathi et al., 2005).

In terms of nutrient losses, the mould board plough and field cultivator were found better than conservation tillage and zero tillage. Highest reduction in organic $\mathrm{N}$ was observed in case of field cultivator $(11.5 \%)$ followed by mould board plough $(5.7 \%)$. However, maximum reduction in organic $\mathrm{P}$ and $\mathrm{NO}_{3}$ were observed in case of the mould board plough $(10.9 \%$ and $16.8 \%$, respectively) followed by the field cultivator (10.7\% and $13.7 \%$, respectively) system. Percentage change analysis of sediment yield and nutrient losses helps in evaluating the effectiveness of management practices in the critical sub-watersheds (Figure 13). Overall, the field cultivator tillage practice with proper extension services to the farmers has been found to be the best tillage practice in minimizing the sediment and nutrient losses in the study area.

Figure 13: Percent change in simulated sediment and nutrients after implementing alternate tillage treatments (T1: zero tillage; T2: conservation tillage; T3: field cultivator; T4: mould board plough) as compared to conventional tillage treatment (country plough)

\subsection{Evaluation of alternate crop management practices}

The SWAT model has been used for evaluation of the BMPs in reducing sediment and nutrient losses by growing four crops viz., rice, maize, soybean and groundnut at three fertilization levels (low, medium and high) (Figure 14). The effects of treatments of these combinations were evaluated to develop suitable management scenarios for each of the sub-watersheds by considering economic status and existing agricultural practices being adopted by the farmers (Jang et al., 2017). The average reduction over the entire critical sub-watersheds for sediment loss was found maximum in case of groundnut (18.6\%, high fertilization level) followed by soybean (16.4\%, medium 
fertilization level). Similarly, average reduction over entire critical sub-watersheds for organic N, organic $\mathrm{P}$ and $\mathrm{NO}_{3}$ were observed as $20.4 \%$ (groundnut, medium fertilization level), $30.8 \%$ (ground nut, medium fertilization level) and $32.2 \%$ (ground nut, high fertilization level), respectively. Thus, the present study revealed that alternate cropping treatments (Groundnut and Soybean) should be encouraged in the steeply-sloped lands along the river of the critical subwatersheds. Changing the current cropping pattern of the watershed can be expensive, especially for the low-income farmers, which in turn can hinder the implementation of the alternate crop management practices. Several interviews of the local farmers, agricultural scientists and district agricultural officers also indicated that replacement of rice with other crops could be difficult in low land areas because rice is staple crop in this region. However, it is advisable to replace maize and rice crop in the steeply-sloped lands along the river areas by some cash crops like soybean or groundnut to reduce the sediment and nutrient loss. The impact of crop and fertilization level treatments on the sediment and nutrient losses from the critical sub-watersheds has been presented

\section{in Figure 14.}

Figure 14: Percent change in simulated sediment and nutrients after implementing different cropfertilization treatments in the critical sub-watersheds as compared to rice cultivation with existing practice of fertilization

\subsection{Evaluation of operation managements}

The SWAT model has been used for evaluating the effectiveness of different operation management strategies (contour farming and filter strips) in reducing sediment yield and nutrient losses. In this study, existing practice of rice cultivation and conventional tillage practices were considered as a base for evaluating operation management strategies. 
Contour farming is similar to terraces in terms of representation in the model and trend in contaminant (sediment, nutrients etc.) reduction. Contour farming reduced the sediment yield by $9.3 \%$ to $38.3 \%$, organic $\mathrm{N}$ by $7.5 \%$ to $26.0 \%$, organic $\mathrm{P}$ by $8.0 \%$ to $22.4 \%$ and $\mathrm{NO}_{3}$ by $12.4 \%$ to $22.4 \%$ in the individual critical sub-watersheds (Figure 15). The maximum reduction of sediment yield (38.3\%) was observed over critical sub-watershed SW-25 after implementation of contour farming practices. Similarly, after implementation of contour farming practices, the maximum reduction of organic $\mathrm{N}(26.0 \%)$, organic $\mathrm{P}(22.4 \%)$ and $\mathrm{NO}_{3}(22.4 \%)$ was observed in the critical sub-watersheds SW-27, SW-25 and SW-8, respectively. Conservation practices in the form of vegetative filter strips were introduced in the critical sub-watersheds to reduce sediment and nutrient losses. Filter strips remove the contaminants (sediment, nutrients etc.) by reducing overland flow velocity resulting in the deposition of particulates. The average reduction over the entire critical sub-watersheds for sediment yield, organic $\mathrm{N}$, organic $\mathrm{P}$ and $\mathrm{NO}_{3}$ were found as $25.4 \%$, $31.4 \%, 34.6 \%$ and $28.3 \%$, respectively. The maximum reduction of sediment yield $(43.3 \%)$ was obtained over critical sub-watershed SW-13 after implementation of filter strips. Similarly, after implementation of filter strips, the maximum reduction of organic $\mathrm{N}(42.5 \%)$, organic $\mathrm{P}(42.0 \%)$ and $\mathrm{NO}_{3}(36.1 \%)$ was observed in the critical sub-watersheds SW-18, SW-6 and SW-17, respectively. However, despite good results, the filter strips are difficult to implement because of maintenance issues, and farmers may not be willing to make the vegetation filter strips by reducing their cultivation areas (Jang et al., 2017). Effect of contour farming and filter strips conservation practices on the sediment and nutrient losses from the critical sub-watersheds with percentage change has been presented in Figure 15. Overall, the sediment yield and nutrient losses from the critical sub-watersheds after simulation of contour farming and filter strips has been observed to 
decline drastically. The present study revealed that the SWAT model can be used to evaluate the effectiveness of agricultural BMPs in the study area efficiently.

Figure 15: Percent reduction in simulated sediment and nutrients after implementing conservation management practices of a) contour farming and b) filter strips in the critical subwatersheds

\section{SUMMARY AND CONCLUSIONS}

In the present study, the SWAT model was used for the evaluation of BMPs in the Marol watershed to recommend appropriate soil conservation measures at the sub-watershed level. Soil erosion status for the entire watershed was generated post model calibration, to prioritize critical sub-watersheds for soil conservation measures. Effectiveness of various land management strategies has been evaluated considering different crops, tillage practices, fertilizer applications and management operations, to understand and reduce sediment and nutrient losses. The water balance study was also carried out to analyze various elements of hydrological processes taking place within the area of interest. Model output resulted in the average annual sediment yield of $12.2 \mathrm{t}^{\mathrm{ha}} \mathrm{ar}^{-1} \mathrm{yr}^{-1}$, and the water balance study showed that evapo-transpiration is predominant and accounting for about $46.3 \%$ of the average annual rainfall falling over the watershed. This study also reveals that the majority of sub-watersheds $(69.7 \%)$ are falling under the slight class of erosion, wherein SW-22 has been identified as a most critical sub-watershed due to steep slope at many locations and inappropriate cultivation practices. High and very high erosion prone areas falling under the watershed are $24.9 \%$, while the severe erosion prone area is about 5.5\%. Results indicated that mould board plough yielded more sediment by $9.5 \%$, while field cultivator, conservation tillage and zero tillage yielded less sediment by $9.0 \%, 6.8 \%$ and $5.4 \%$, respectively as compare to conventional tillage. As far as nutrient losses concerned, mould board plough and field cultivator are better than conservation tillage and zero tillage. Maximum reduction in organic $\mathrm{N}$ was observed in case of field cultivator $(11.5 \%)$ followed by mould board plough $(5.7 \%)$. However, maximum reduction in organic $\mathrm{P}$ and $\mathrm{NO}_{3}$ were observed in case of the mould board plough $(10.9 \%$ and $16.8 \%$, respectively) followed by field cultivator (10.7\% and $13.7 \%$, respectively) system. Higher reduction in sediment yield and nutrient loss was observed due to alternate cropping treatments of Groundnut and Soybean, as compared to paddy and maize cultivation. Overall, based on simulated results, the field cultivator tillage practice (to replace conventional tillage) and conservation 
practices viz., contour farming and filter strips, could be very useful to reduce sediment yield and nutrient losses in the critical sub-watersheds of the present study area. These conservation practices can be applied to watersheds with similar hydro-climatic conditions. However, future studies should be carried out to investigate the cost-effectiveness of the suggested management practices. A multiobjective optimization technique can also be coupled with the SWAT model to optimize the selection and placement of BMPs to a balance of desired economic feasibility and environmental outcomes. In this study, analysis was carried out with the assumption that land use/land cover and other model parameters remain constant with time, however, in reality several parameters change with time/season. Therefore, similar study with incorporation of dynamic land use/land cover and variable model parameters could be carried out in future to develop more realistic and effective management plans. 


\section{REFERENCES}

Abbaspour, K. C., Vejdani, M., and Haghighat, S. (2007). SWAT-CUP calibration and uncertainty programs for SWAT. In MODSIM 2007 International Congress on Modelling and Simulation, Modelling and Simulation Society of Australia and New Zealand, 1603-1609.

Akiner, M. E., and Akkoyunlu, A. (2012). Modeling and forecasting river flow rate from the Melen Watershed, Turkey. Journal of hydrology, 456, 121-129.

Arnold J. G. and Fohrer N. (2005) SWAT 2000: current capabilities and research opportunities in applied watershed modelling. Hydrological processes, 19(3), 563-572.

Arnold, J. G., Srinivasan, R., Muttiah, R. S., and Williams, J. R. (1998). Large area hydrologic modeling and assessment part I: Model development 1. Journal of the American Water Resources Association, 34(1), 73-89.

Arnold, J. G., Williams, J. R., Srinivasan, R., \& King, K. W. (1996). Soil and Water Assessment Tool, User's Manual. USDA, Agriculture Research Service, Grassland, Soil and Water Research Laboratory, Temple, TX.

Asl-Rousta, B., Mousavi, S. J., Ehtiat, M., \& Ahmadi, M. (2018). SWAT-Based Hydrological Modelling Using Model Selection Criteria. Water Resources Management, 32(6), 2181-2197.

Behera, S., and Panda, R. K. (2006). Evaluation of management alternatives for an agricultural watershed in a sub-humid subtropical region using a physical process based model. Agriculture, ecosystems and environment, 113(1), 62-72.

Betrie, G. D., Mohamed, Y. A., van Griensven, A., and Srinivasan, R. (2011). Sediment management modelling in the Blue Nile Basin using SWAT model. Hydrology and Earth System Sciences, 15(3), 807.

Borah, D. K., Arnold, J. G., Bera, M., Krug, E. C., and Liang, X. Z. (2007). Storm event and continuous hydrologic modeling for comprehensive and efficient watershed simulations. Journal of Hydrologic Engineering, 12(6), 605-616.

Borah, D. K., and Bera, M. (2003). Watershed-scale hydrologic and nonpoint-source pollution models: Review of mathematical bases. Transactions of the ASAE, 46(6), 1553. 
Bossa, A. Y., Diekkrüger, B., Giertz, S., Steup, G., Sintondji, L. O., Agbossou, E. K., and Hiepe, C. (2012). Modeling the effects of crop patterns and management scenarios on $\mathrm{N}$ and $\mathrm{P}$ loads to surface water and groundwater in a semi-humid catchment (West Africa). Agricultural water management, 115, 20-37.

Brighenti, T. M., Bonumá, N. B., Grison, F., de Almeida Mota, A., Kobiyama, M., \& Chaffe, P. L. B. (2019). Two calibration methods for modeling streamflow and suspended sediment with the swat model. Ecological Engineering, 127, 103-113.

Chiang, L. C., Chaubey, I., Maringanti, C., \& Huang, T. (2014). Comparing the selection and placement of best management practices in improving water quality using a multiobjective optimization and targeting method. International journal of environmental research and public health, 11(3), 2992-3014.

Choi, J. Y., Engel, B. A., \& Chung, H. W. (2002). Daily streamflow modelling and assessment based on the curve-number technique. Hydrological Processes, 16(16), 3131-3150.

Conley, D. J., Paerl, H. W., Howarth, R. W., Boesch, D. F., Seitzinger, S. P., Havens, K. E., Lancelot, C., and Likens, G. E. (2009). Controlling eutrophication: nitrogen and phosphorus. Science, 323, 1014-1015.

Dabral, P. P., and Pandey, A. (2007). Morphometric analysis and prioritization of eastern Himalayan River basin using Satellite data and GIS. Asian J Geoinformatics, 7(3), 3-14.

den Biggelaar, C., Lal R., Wiebe, K., Breneman V., Reich P. (2004b). The Global Impact of Soil Erosion on Productivity II: Effects on Crop Yields and Production over Time. Advances in Agronomy, 81, 49-95.

den Biggelaar, C., Lal R., Wiebe, K., Breneman, V. (2004a). The Global Impact of Soil Erosion on Productivity I: Absolute and Relative Erosion-Induced Yield Losses. Advances in Agronomy, $81,1-48$.

Dhami, B., Himanshu, S. K., Pandey, A., \& Gautam, A. K. (2018). Evaluation of the SWAT model for water balance study of a mountainous snowfed river basin of Nepal. Environmental Earth Sciences, 77(1), 21. 
Dile, Y.T., Srinivasan, R., 2014. Evaluation of CFSR climate data for hydrologic prediction in datascarce watersheds: an application in the blue nile river basin. J. Am. Water Resour. Assoc. 50, $1226-1241$.

Dong, F., Liu, Y., Wu, Z., Chen, Y., \& Guo, H. (2018). Identification of watershed priority management areas under water quality constraints: A simulation-optimization approach with ideal load reduction. Journal of Hydrology, 562, 577-588.

Duchemin, M., \& Hogue, R. (2009). Reduction in agricultural non-point source pollution in the first year following establishment of an integrated grass/tree filter strip system in southern Quebec (Canada). Agriculture, Ecosystems \& Environment, 131(1), 85-97.

EPA. (1976). Quality Criteria for Water. Environmental Protection Agency, Washington, DC.

Garg, K. K., Bharati, L., Gaur, A., George, B., Acharya, S., Jella, K., and Narasimhan, B. (2012). Spatial mapping of agricultural water productivity using the SWAT model in Upper Bhima Catchment, India. Irrigation and Drainage, 61(1), 60-79.

Gildow, M., Aloysius, N., Gebremariam, S., \& Martin, J. (2016). Fertilizer placement and application timing as strategies to reduce phosphorus loading to Lake Erie. Journal of Great Lakes Research, 42(6), 1281-1288.

Gopinath, G., Nair, A. G., Ambili, G. K., and Swetha, T. V. (2016). Watershed prioritization based on morphometric analysis coupled with multi criteria decision making. Arabian Journal of Geosciences, 9(2), 1-17.

Gupta, H. V., Sorooshian, S., and Yapo, P. O. (1999). Status of automatic calibration for hydrologic models: Comparison with multilevel expert calibration. Journal of Hydrologic Engineering, $4(2), 135-143$.

Guto, S. N., Pypers, P., Vanlauwe, B., de Ridder, N., and Giller, K. E. (2011). Tillage and vegetative barrier effects on soil conservation and short-term economic benefits in the Central Kenya highlands. Field Crops Research, 122(2), 85-94.

Her, Y., Chaubey, I., Frankenberger, J., and Jeong, J. (2017). Implications of spatial and temporal variations in effects of conservation practices on water management strategies. Agricultural Water Management, 180, 252-266. 
Herman, M. R., Nejadhashemi, A. P., Daneshvar, F., Ross, D. M., Woznicki, S. A., Zhang, Z., \& Esfahanian, A. H. (2015). Optimization of conservation practice implementation strategies in the context of stream health. Ecological Engineering, 84, 1-12.

Himanshu, S. K., Pandey, A., \& Patil, A. (2018). Hydrologic Evaluation of the TMPA-3B42V7 Precipitation Data Set over an Agricultural Watershed Using the SWAT Model. Journal of Hydrologic Engineering, 23(4), 05018003.

Himanshu, S. K., Pandey, A., and Shrestha, P. (2017). Application of SWAT in an Indian river basin for modeling runoff, sediment and water balance. Environmental Earth Sciences, 76(1), 3.

Humenik FJ, Smolen MD, Dressing SA. 1987. Pollution from nonpoint sources: where we are and where we should go. Environmental Science and Technology 21(8): 737-742.

Jang, S. S., Ahn, S. R., and Kim, S. J. (2017). Evaluation of executable best management practices in Haean highland agricultural catchment of South Korea using SWAT. Agricultural Water Management, 180, 224-234.

Kim, N. W., \& Lee, J. (2008). Temporally weighted average curve number method for daily runoff simulation. Hydrological Processes: An International Journal, 22(25), 4936-4948.

Lam, Q. D., Schmalz, B., and Fohrer, N. (2011). The impact of agricultural Best Management Practices on water quality in a North German lowland catchment. Environmental monitoring and assessment, 183(1-4), 351-379.

Lamba, J., Thompson, A. M., Karthikeyan, K. G., Panuska, J. C., \& Good, L. W. (2016). Effect of best management practice implementation on sediment and phosphorus load reductions at subwatershed and watershed scale using SWAT model. International Journal of Sediment Research, 31(4), 386-394.

Lampurlanés, J., Plaza-Bonilla, D., Álvaro-Fuentes, J., and Cantero-Martínez, C. (2016). Longterm analysis of soil water conservation and crop yield under different tillage systems in Mediterranean rainfed conditions. Field Crops Research, 189, 59-67.

Liu, R., Xu, F., Zhang, P., Yu, W., \& Men, C. (2016). Identifying non-point source critical source areas based on multi-factors at a basin scale with SWAT. Journal of Hydrology, 533, 379-388. 
Maharjan, G. R., Ruidisch, M., Shope, C. L., Choi, K., Huwe, B., Kim, S. J., Tenhunen, J., and Arnhold, S. (2016). Assessing the effectiveness of split fertilization and cover crop cultivation in order to conserve soil and water resources and improve crop productivity. Agricultural Water Management, 163, 305-318.

Mannering, J. V. (1981). The use of soil tolerances as strategy for soil conservation. In Soil Conservation Problem and Prospect, MorganRPC (ed.). John Wiley: Chichester, UK; 337-349.

McGregor, K. C., Cullum, R. F., and Mutchler, C. K. (1999). Long-term management effects on runoff, erosion, and crop production. Transactions of the ASAE-American Society of Agricultural Engineers, 42(1), 99-106.

Merriman, K. R., Russell, A. M., Rachol, C. M., Daggupati, P., Srinivasan, R., Hayhurst, B. A., \& Stuntebeck, T. D. (2018). Calibration of a Field-Scale Soil and Water Assessment Tool (SWAT) Model with Field Placement of Best Management Practices in Alger Creek, Michigan. Sustainability, 10(3), 851.

Moriasi D. N., Arnold J. G., Van Liew M. W., Bingner R. L., Harmel R. D. and Veith T. L. (2007). Model evaluation guidelines for systematic quantification of accuracy in watershed simulations. Trans. ASABE, 50(3), 885-900.

Murty, P. S., Pandey, A., and Suryavanshi, S. (2014). Application of semi-distributed hydrological model for basin level water balance of the Ken basin of Central India. Hydrological processes, 28(13), 4119-4129.

Neitsch, S. L., Arnold, J.G., Kiniry, J. R., and Williams, J. R. (2011). Soil and Water Assessment Tool Theoretical Documentation Version 2009. Texas Water Resources Institute Technical Report No. 406, Texas Aand M University System, College Station, Texas.

Ng, S. L., Cai, Q. G., Ding, S. W., Chau, K. C., and Qin, J. (2008). Effects of contour hedgerows on water and soil conservation, crop productivity and nutrient budget for slope farmland in the Three Gorges Region (TGR) of China. Agroforestry systems, 74(3), 279-291.

Ni, X., \& Parajuli, P. B. (2018). Evaluation of the impacts of BMPs and tailwater recovery system on surface and groundwater using satellite imagery and SWAT reservoir function. Agricultural water management, 210, 78-87. 
Niraula, R., Kalin, L., Srivastava, P., and Anderson, C. J. (2013). Identifying critical source areas of nonpoint source pollution with SWAT and GWLF. Ecological Modelling, 268, 123-133.

Niraula, R., Kalin, L., Wang, R., \& Srivastava, P. (2011). Determining nutrient and sediment critical source areas with SWAT: effect of lumped calibration. Transactions of the ASABE, 55(1), 137147.

Noor, H., Fazli, S., Rostami, M., and Kalat, A. B. (2017). Cost-effectiveness analysis of different watershed management scenarios developed by simulation-optimization model. Water Science and Technology: Water Supply, ws2017029.

NRSC (2014). Land Use / Land Cover database on 1:50,000 scale, Natural Resources Census Project, LUCMD, LRUMG, RSAA, National Remote Sensing Centre, ISRO, Hyderabad.

Oeurng, C., Sauvage, S., and Sánchez-Pérez, J. M. (2011). Assessment of hydrology, sediment and particulate organic carbon yield in a large agricultural catchment using the SWAT model. Journal of Hydrology, 401(3), 145-153.

Pai, D. S., Sridhar, L., Badwaik, M. R., and Rajeevan, M. (2015). Analysis of the daily rainfall events over India using a new long period (1901-2010) high resolution $(0.25 \times 0.25)$ gridded rainfall data set. Climate Dynamics, 45(3-4), 755-776.

Pai, D. S., Sridhar, L., Rajeevan, M., Sreejith, O. P., Satbhai, N. S., and Mukhopadhyay, B. (2014). Development of a new high spatial resolution $(0.25 \times 0.25)$ long period (1901-2010) daily gridded rainfall data set over India and its comparison with existing data sets over the region. Mausam, 65(1), 1-18.

Pandey, A., Chowdary, V. M., and Mal, B. C. (2007). Identification of critical erosion prone areas in the small agricultural watershed using USLE, GIS and remote sensing. Water resources management, 21(4), 729-746.

Pandey, A., Chowdary, V. M., Mal, B. C., and Billib, M. (2009a). Application of the WEPP model for prioritization and evaluation of best management practices in an Indian watershed. Hydrological processes, 23(21), 2997-3005.

Pandey, A., Himanshu, S. K., Mishra, S. K., and Singh, V. P. (2016). Physically based soil erosion and sediment yield models revisited. CATENA, 147, 595-620. 
Pandey, A., Lalrempuia, D., and Jain, S. K. (2015). Assessment of hydropower potential using spatial technology and SWAT modelling in the Mat River, southern Mizoram, India. Hydrological Sciences Journal, 60(10), 1651-1665.

Pandey, V. K., Panda, S. N., and Sudhakar, S. (2005). Modelling of an agricultural watershed using remote sensing and a geographic information system. Biosystems Engineering, 90(3), 331-347.

Pandey, V. K., Panda, S. N., Pandey, A., and Sudhakar, S. (2009b). Evaluation of effective management plan for an agricultural watershed using AVSWAT model, remote sensing and GIS. Environmental Geology, 56(5), 993-1008.

Pare, M. C., Lafond, J., and Pageau, D. (2015). Best management practices in Northern agriculture: A twelve-year rotation and soil tillage study in Saguenay-Lac-Saint-Jean. Soil and Tillage Research, 150, 83-92.

Pradhan, P., Fischer, G., van Velthuizen, H., Reusser, D.E., Kropp, J.P., 2015. Closing Yield Gaps: How Sustainable Can We Be? PLoS One 10, e0129487.

Prasad, B., Honda, S. K., and Murai, S. (1997). Sub-watershed prioritization of watershed management, eastern region, Nepal, using remote sensing and GIS. http:/www. gistdevelopment. net/AARS/ACRS/Water resources.

Prasad, R. (2002). Text Book of Field Crop Production, ICAR, New Delhi.

Pyo, J., Baek, S. S., Kim, M., Park, S., Lee, H., Ra, J. S., \& Cho, K. H. (2017). Optimizing Agricultural Best Management Practices in a Lake Erie Watershed. JAWRA Journal of the American Water Resources Association, 53(6), 1281-1292.

Qiu, J., Shen, Z., Huang, M., \& Zhang, X. (2018). Exploring effective best management practices in the Miyun reservoir watershed, China. Ecological engineering, 123, 30-42.

Qiu, L. J., Zheng, F. L., and Yin, R. S. (2012). SWAT-based runoff and sediment simulation in a small watershed, the loessial hilly-gullied region of China: capabilities and challenges. International Journal of Sediment Research, 27(2), 226-234.

Rocha, E. O., Calijuri, M. L., Santiago, A. F., de Assis, L. C., and Alves, L. G. S. (2012). The contribution of conservation practices in reducing runoff, soil loss, and transport of nutrients at the watershed level. Water resources management, 26(13), 3831-3852. 
Rocha, J., Roebeling, P., and Rial-Rivas, M. E. (2015). Assessing the impacts of sustainable agricultural practices for water quality improvements in the Vouga catchment (Portugal) using the SWAT model. Science of The Total Environment, 536, 48-58.

Saha, S., Moorthi, S., Pan, H.L., Wu, X., Wang, J., Nadiga, S., Tripp, P., Kistler, R., Woollen, J., Behringer, D., Liu, H., Stokes, D., Grumbine, R., Gayno, G., Wang, J., Hou, Y.T., Chuang, H.Y., Juang, H.M.H., Sela, J., Iredell, M., Treadon, R., Kleist, D., Van Delst, P., Keyser, D., Derber, J., Ek, M., Meng, J., Wei, H., Yang, R., Lord, S., Van Den Dool, H., Kumar, A., Wang, W., Long, C., Chelliah, M., Xue, Y., Huang, B., Schemm, J.K., Ebisuzaki, W., Lin, R., Xie, P., Chen, M., Zhou, S., Higgins, W., Zou, C. Z., Liu, Q., Chen, Y., Han, Y., Cucurull, L., Reynolds, R.W., Rutledge, G., Goldberg, M., 2010. The NCEP climate forecast system reanalysis. Bull. Am. Meteorol. Soc. 91, 1015-1057.

Sakthivadivel, R., Aloysius, N., and Matsuno, Y. (2001). Assessment of performance and impact of irrigation and water resources systems in Taiwan and Sri Lanka (Vol. 31). IWMI.

Shepard, D. (1968). A two-dimensional interpolation function for irregularly-spaced data. In Proceedings of the 1968, 23rd ACM national conference, 517-524.

Shivaprasad, C. R., Reddy, R. S., Sehgal, J., \&Velayutham, M. (1998). Soils of Karnataka for optimizing land use. NBSS Publ. 47b (Soils of India Series). Nagpur, India: National Bureau of Soil Survey and Land Use Planning.

Singh, C., Singh, P. and Singh, R. (2003). Modern Techniques of Raising Field Crops, Oxford and IBH, New Delhi.

Singh, G., Babu, R., Narain, P., Bhushan, L. S., and Abrol, I. P. (1992). Soil erosion rates in India. Journal of Soil and Water Conservation, 47(1), 97-99.

Singh, V. P. (1995). Computer models of watershed hydrology. Chapter 1: Watershed Modelling. Water Resources Publications, Colorado.

Srinivasan, R., Ramanarayanan, T. S., Arnold, J. G. and Bednarz, S. T. (1998). Large area hydrologic modeling and assessment part II: Model application, J. American Water Resources Association, 34(1): 91-101. 
Srivastava, A.K., Raajeevan, M., Kshirsagar, S.R.(2009). Development of a high resolution daily gridded temperature data set (1969-2005) for the Indian region. Atmos. Sci. Lett. 10 (October), 249-254.

Srivastava, P., Edwards, D. R., Daniel, T. C., Moore, P. A., and Costello, T. A. (1996). Performance of vegetative filter strips with varying pollutant source and filter strip lengths. Transactions of the ASAE-American Society of Agricultural Engineers, 39(6), 2231-2240.

Strauch, M., Lima, J. E., Volk, M., Lorz, C., \& Makeschin, F. (2013). The impact of Best Management Practices on simulated streamflow and sediment load in a Central Brazilian catchment. Journal of environmental management, 127, S24-S36.

Strehmel, A., Schmalz, B., and Fohrer, N. (2016). Evaluation of Land Use, Land Management and Soil Conservation Strategies to Reduce Non-Point Source Pollution Loads in the Three Gorges Region, China. Environmental management, 58(5), 906-921.

Sudheer, K. P., Chaubey, I., Garg, V., \& Migliaccio, K. W. (2007). Impact of time-scale of the calibration objective function on the performance of watershed models. Hydrological Processes: An International Journal, 21(25), 3409-3419.

Tilman, D., Cassman, K.G., Matson, P.A., Naylor, R., Polasky, S., 2002. Agriculturalsustainability and intensive production practices. Nature 418, 671-677.

Tim, U. S., Mostaghimi, S., and Shanholtz, V. O. (1992). Identification of critical nonpoint pollution source areas using geographic information systems and water quality modeling. JAWRA Journal of the American Water Resources Association, 28(5), 877-887.

Tripathi, M. P., Panda, R. K., and Raghuwanshi, N. S. (2003). Identification and prioritisation of critical sub-watersheds for soil conservation management using the SWAT model. Biosystems Engineering, 85(3), 365-379.

Tripathi, M. P., Panda, R. K., and Raghuwanshi, N. S. (2005). Development of effective management plan for critical subwatersheds using SWAT model. Hydrological processes, 19(3), 809-826.

Tripathi, M. P., Verma, M. K., and Agrawal, N. (2013). Management Scenario for the Critical Subwatersheds of Small Agricultural Watershed using SWAT model and GIS Technique. In 2012 International SWAT Conference Proceedings. 
Tsuchiya, R., Kato, T., Jeong, J., \& Arnold, J. (2018). Development of SWAT-Paddy for Simulating Lowland Paddy Fields. Sustainability, 10(9), 3246.

Tuppad, P., Kannan, N., Srinivasan, R., Rossi, C. G., \& Arnold, J. G. (2010). Simulation of agricultural management alternatives for watershed protection. Water Resources Management, 24(12), 3115-3144.

Ullrich, A., and Volk, M. (2009). Application of the Soil and Water Assessment Tool (SWAT) to predict the impact of alternative management practices on water quality and quantity. Agricultural Water Management, 96(8), 1207-1217.

Uribe, N., Corzo, G., Quintero, M., van Griensven, A., \& Solomatine, D. (2018). Impact of conservation tillage on nitrogen and phosphorus runoff losses in a potato crop system in Fuquene watershed, Colombia. Agricultural water management, 209, 62-72.

Wang, R., Liu, Z., Yao, Z., \& Lei, Y. (2014). Modeling the risk of nitrate leaching and nitrate runoff loss from intensive farmland in the Baiyangdian Basin of the North China Plain. Environmental Earth Sciences, 72(8), 3143-3157.

Wang, W., Xie, Y., Bi, M., Wang, X., Lu, Y., \& Fan, Z. (2018). Effects of best management practices on nitrogen load reduction in tea fields with different slope gradients using the SWAT model. Applied Geography, 90, 200-213.

Wei, X., Bailey, R., and Tasdighi, A. (2018). Using the SWAT Model in Intensively Managed Irrigated Watersheds: Model Modification and Application. Journal of Hydrologic Engineering, 23(10): 04018044.

Xie, H., Chen, L., and Shen, Z. (2015). Assessment of Agricultural Best Management Practices Using Models: Current Issues and Future Perspectives. Water, 7(3), 1088-1108.

Xu, Z. X., Pang, J. P., Liu, C. M., and Li, J. Y., (2009). Assessment of runoff and sediment yield in the Miyun Reservoir catchment by using SWAT model. Hydrological processes, 23(25), 36193630.

Yang, G. X., and Best, E. P. H. (2015). Spatial optimization of watershed management practices for nitrogen load reduction using a modeling-optimization framework. Journal of Environmental Management, 161, 252e260. 
Zhang, X., and Zhang, M. (2011). Modeling effectiveness of agricultural BMPs to reduce sediment load and organophosphate pesticides in surface runoff. Science of the Total Environment, 409(10), 1949-1958. 
Table 1: Datasets used in the present study

\begin{tabular}{|c|c|c|c|c|c|}
\hline Data category & Dataset & Source & $\begin{array}{l}\text { Scale/Spatial } \\
\text { Resolution }\end{array}$ & Period & URL/Reference \\
\hline \multirow[t]{5}{*}{ Weather data } & Rainfall & IMD Gridded & $0.25^{\circ} \times 0.25^{\circ}$ & $\begin{array}{l}1998- \\
2011\end{array}$ & Pai et al. $(2014,2015)$ \\
\hline & Temperature & IMD Gridded & $1^{\circ} \times 1^{\circ}$ & $\begin{array}{l}1998- \\
2011\end{array}$ & Srivastava et al. (2009) \\
\hline & Humidity & NCEP-CFSR & $0.25^{\circ} \times 0.25^{\circ}$ & $\begin{array}{l}1998- \\
2011\end{array}$ & http://globalweather.tamu.edu/ \\
\hline & Wind Speed & NCEP-CFSR & $0.25^{\circ} \times 0.25^{\circ}$ & $\begin{array}{l}1998- \\
2011\end{array}$ & http://globalweather.tamu.edu/ \\
\hline & $\begin{array}{l}\text { Solar } \\
\text { Radiation }\end{array}$ & NCEP-CFSR & $0.25^{\circ} \times 0.25^{\circ}$ & $\begin{array}{l}1998- \\
2011\end{array}$ & http://globalweather.tamu.edu/ \\
\hline \multirow[t]{2}{*}{$\begin{array}{l}\text { Hydrological } \\
\text { data }\end{array}$} & Runoff & CWC Gauge & - & $\begin{array}{l}1998- \\
2011\end{array}$ & http://india-wris.nrsc.gov.in/ \\
\hline & Sediment & CWC Gauge & - & $\begin{array}{l}1998- \\
2011\end{array}$ & http://india-wris.nrsc.gov.in/ \\
\hline \multirow[t]{3}{*}{ Thematic Data } & Topography & $\begin{array}{l}\text { ASTER } \\
\text { GDEM }\end{array}$ & $30 \mathrm{~m}$ & 2008 & http://earthexplorer.usgs.gov/ \\
\hline & Land use & NRSC, ISRO & $1: 50,000$ & 2011 & NRSC (2014) \\
\hline & Soil & NBSS\&LUP & $1: 250,000$ & 1998 & Shivaprasad et al. (1998) \\
\hline
\end{tabular}


Table 2: Detailed land use, soil and slope distribution over the Marol watershed

\begin{tabular}{|c|c|c|c|}
\hline \multicolumn{2}{|c|}{ Land use/soil/slope distribution } & \multirow{2}{*}{$\begin{array}{l}\text { Area [ha] } \\
394953.1\end{array}$} & \multirow{2}{*}{$\begin{array}{l}\text { \% Watershed Area } \\
77.6\end{array}$} \\
\hline Land use & Agricultural Land-Generic (AGRL) & & \\
\hline & Forest-Deciduous (FRSD) & 54671.1 & 10.7 \\
\hline & Pasture (PAST) & 27364.7 & 5.4 \\
\hline & Forest-Evergreen (FRSE) & 23250.0 & 4.6 \\
\hline & Water (WATR) & 5578.1 & 1.1 \\
\hline & Forest-Mixed (FRST) & 2310.8 & 0.5 \\
\hline & Residential (URBN) & 695.4 & 0.1 \\
\hline & Range-Grasses (RNGE) & 330.4 & 0.1 \\
\hline & Orchard (ORCD) & 30.4 & Negligible \\
\hline & Range-Brush (RNGB) & 11.8 & Negligible \\
\hline \multirow[t]{7}{*}{ Soils } & Silty Clay & 158395.6 & 31.1 \\
\hline & Sandy Clay Loam & 142606.9 & 28.0 \\
\hline & Clay & 77981.1 & 15.3 \\
\hline & Sandy Clay & 57112.9 & 11.2 \\
\hline & Clay Loam & 36013.1 & 7.1 \\
\hline & Loam & 35684.5 & 7.0 \\
\hline & Loamy Sand & 1401.7 & 0.3 \\
\hline \multirow[t]{4}{*}{ Slope } & $0-2.8$ & 300602.8 & 59.0 \\
\hline & $2.8-6.3$ & 155211.1 & 30.5 \\
\hline & $6.3-14.2$ & 48832.0 & 9.6 \\
\hline & $>14.2$ & 4549.8 & 0.9 \\
\hline
\end{tabular}


Table 3: Discharge and sediment load sensitivity order of the SWAT model parameters for the Marol Watershed

\begin{tabular}{|c|c|c|c|c|c|c|c|}
\hline \multicolumn{4}{|l|}{ Discharge } & \multicolumn{4}{|c|}{ Suspended Sediment Load } \\
\hline $\begin{array}{l}\text { Sensitivity } \\
\text { order }\end{array}$ & Parameters $^{\#}$ & $\begin{array}{l}\text { Range used for } \\
\text { calibration }\end{array}$ & $\begin{array}{l}\text { Calibrated } \\
\text { value }\end{array}$ & $\begin{array}{l}\text { Sensitivity } \\
\text { order }\end{array}$ & Parameters $^{\#}$ & $\begin{array}{l}\text { Range used for } \\
\text { calibration }\end{array}$ & $\begin{array}{l}\text { Calibrated } \\
\text { value }\end{array}$ \\
\hline 1 & $\mathrm{v} \_\mathrm{CH}$ _N2.rte & 0.01 to 0.3 & 0.20 & 1 & v_OV_N.hru & 0.01 to 30 & 23.09 \\
\hline 2 & v_CH_K2.rte & 100 to 500 & 377.20 & 2 & v__USLE_P.mgt & 0 to 1 & 0.81 \\
\hline 3 & $\mathrm{r} \_\mathrm{CN} 2 . \mathrm{mgt}$ & $-20 \%$ to $+20 \%$ & $0.11 \%$ & 3 & $\mathrm{r} \_\mathrm{CN} 2 . \mathrm{mgt}$ & $-30 \%$ to $+10 \%$ & $-23.59 \%$ \\
\hline 4 & v_ALPHA_BF.gw & 0.8 to 1 & 0.81 & 4 & r_USLE_K.hru & $-50 \%$ to $+30 \%$ & $0.43 \%$ \\
\hline 5 & $\mathrm{v} \_$RCHRG_DP.gw & 0 to 1 & 0.86 & 5 & v_CH_K1.sub & 0 to 300 & 16.27 \\
\hline 6 & r_SOL_K.sol & $-20 \%$ to $+20 \%$ & $-0.17 \%$ & 6 & v_ESCO.hru & 0 to 1 & 0.43 \\
\hline 7 & $\mathrm{v}_{\text {_EPCO.hru }}$ & 0 to 1 & 0.98 & 7 & v_RCHRG_DP.gw & 0 to 1 & 0.83 \\
\hline 8 & r__SLSUBBSN.hru & $-20 \%$ to $+20 \%$ & $14.68 \%$ & 8 & v_ALPHA_BF.gw & 0.6 to 1 & 0.86 \\
\hline 9 & a_GWQMN.gw & -1000 to +1000 & -798.00 & 9 & v_EPCO.hru & 0 to 1 & 0.48 \\
\hline 10 & r_SOL_AWC.sol & $-20 \%$ to $+20 \%$ & $-0.09 \%$ & 10 & r__SLSUBBSN.hru & $-20 \%$ to $+20 \%$ & $13.65 \%$ \\
\hline 11 & v_GW_REVAP.gw & 0.02 to 0.2 & 0.15 & 11 & $\mathrm{v} \_$SURLAG.bsn & 0.05 to 24 & 16.37 \\
\hline 12 & a_GW_DELAY.gw & 0 to 470 & 67.21 & 12 & v_GW_REVAP.gw & 0.02 to 0.2 & 0.05 \\
\hline 13 & $\mathrm{v}_{\text {_SURLAG.bsn }}$ & 0.05 to 24 & 18.23 & 13 & v_CH_K2.rte & 0 to 500 & 180.87 \\
\hline 14 & a_REVAPMN.gw & -100 to +300 & -13.99 & 14 & $\mathrm{~V}_{\text {_BBIOMIX.mgt }}$ & 0 to 1 & 0.46 \\
\hline 15 & $\mathrm{v}_{\text {_ESCO.hru }}$ & 0 to 1 & 0.93 & 15 & v_CH_N2.rte & 0.01 to 0.3 & 0.21 \\
\hline 16 & v_CH_S1.sub & 0.0001 to 10 & 4.19 & 16 & a_GWQMN.gw & -1000 to +1000 & -85.50 \\
\hline 17 & v_CH_COV2.rte & 0.5 to 1 & 0.91 & 17 & v_CH_COV2.rte & 0.001 to 1 & 0.055 \\
\hline
\end{tabular}

${ }^{\#}$ The initials represent the method used for defining the parameter range in auto-calibration; $r=$ relative change to initial value, $v=$ replacement of value within given range, $a=$ absolute change with respect to the default value. The extension in the parameter file name represents the processes controlled by the parameter; $m g t=$ crop cover management, $g w=$ groundwater, sol $=$ soil water dynamics, $b$ sn $=$ entire watershed scale, rte $=$ water routing, hru $=$ water dynamics at HRU level.

Parameter description: $A L P H A \_B F=B a s e-f l o w$ alpha factor (days); BIOMIX = Biological mixing efficiency; CH_COV2 = Channel coverfactor; CH_K1 = Effective hydraulic conductivity in tributary channel alluvium; $C H \_K 2=$ Effective hydraulic conductivity in main channel alluvium; $C H \_N 2=$ Manning's " $n$ " value for the main channel; CH_S1 = Average slope of tributary channels; CN2 = SCS runoff curve number; EPCO = Plant uptake compensation factor; $E S C O=$ Soil evaporation compensation factor; GW DELAY = Groundwater delay (days); GWOMN = Threshold depth of water required for return flow to occur in the shallow aquifer $(\mathrm{mm}) ; W_{-}$REVAP = Groundwater "revap" coefficient; $O V_{-} N=$ Manning's " $n$ " value for overland flow; RCHRG_DP = Deep aquifer percolation fraction; REVAPMN = Threshold depth of water in the shallow aquifer for "revap" to occur (mm); SLSUBBSN = Average slope length; SOL_AWC = Available water capacity of the soil layer; SOL_K = Saturated hydraulic conductivity; SURLAG = Surface runoff lag time; USLE_K = USLE equation soil erodibility $(K)$ factor; USLE_P $=U S L E$ equation support practices $(P)$ factor. 
Table 4: Tillage treatments considered for effective management

\begin{tabular}{llll}
\hline Code & Tillage treatments & Mixing efficiency & Tillage Depth $(\mathbf{m m})$ \\
\hline T1 & Zero tillage & 0.05 & 10 \\
T2 & Conservation tillage & 0.25 & 40 \\
T3 & Field cultivator & 0.30 & 50 \\
T4 & Mould board plough & 0.90 & 150 \\
\hline
\end{tabular}

2

3

4

5

6

9

10

11

12

Table 5: Fertilization level with values of $\mathrm{N}$ : P (kg/ha) for various crops considered for management

\begin{tabular}{|c|c|c|c|c|c|c|c|c|c|c|}
\hline \multicolumn{2}{|c|}{$\begin{array}{l}\text { Fertilization } \\
\text { Level }\end{array}$} & \multicolumn{2}{|c|}{$\begin{array}{l}\text { Maize } \\
\text { (Zea mays) }\end{array}$} & \multicolumn{2}{|c|}{$\begin{array}{l}\text { Rice } \\
\text { (Oryza sativa) }\end{array}$} & \multicolumn{2}{|c|}{$\begin{array}{l}\text { Soybean } \\
\text { (Glycine max) }\end{array}$} & \multicolumn{3}{|c|}{$\begin{array}{l}\text { Groundnut } \\
\text { (Arachis hypogaea) }\end{array}$} \\
\hline \multicolumn{2}{|c|}{ Low } & \multicolumn{2}{|c|}{ F1 $(20: 15)$} & \multicolumn{2}{|c|}{$\mathrm{F} 4(25: 15)$} & \multicolumn{2}{|c|}{ F7 (10:20) } & \multicolumn{3}{|c|}{ F10 $(10: 20)$} \\
\hline \multicolumn{2}{|c|}{ Medium } & \multicolumn{2}{|c|}{$\mathrm{F} 2(50: 30)$} & \multicolumn{2}{|c|}{ F5 $(40: 30)$} & \multicolumn{2}{|c|}{$\mathrm{F} 8(30: 30)$} & \multicolumn{3}{|c|}{ F11 (20 : 40) } \\
\hline \multicolumn{2}{|c|}{ High } & \multicolumn{2}{|c|}{ F3 (100: 60) } & \multicolumn{2}{|c|}{ F6 $(80: 60)$} & \multicolumn{2}{|c|}{ F9 $(60: 60)$} & \multicolumn{3}{|c|}{ F12 (30 : 60) } \\
\hline \multicolumn{11}{|c|}{ Table 6: Performance evaluation of the SWAT model } \\
\hline \multirow{3}{*}{ Sr. No. } & \multirow{3}{*}{\multicolumn{2}{|c|}{ Parameter }} & \multicolumn{3}{|c|}{ Total stream flow } & & \multicolumn{4}{|c|}{ Suspended sediment load } \\
\hline & & & \multicolumn{2}{|l|}{ Daily } & \multicolumn{2}{|c|}{ Monthly } & \multicolumn{2}{|l|}{ Daily } & \multicolumn{2}{|c|}{ Monthly } \\
\hline & & & Cal & Val & Cal & Val & Cal & Val & Cal & Val \\
\hline 1. & NSE & & 0.82 & 0.74 & 0.83 & 0.78 & 0.69 & 0.63 & 0.73 & 0.71 \\
\hline 2. & PBIAS & & -1.58 & 10.25 & -12.46 & 7.77 & -25.16 & 26.24 & -22.69 & 16.59 \\
\hline 3. & $\mathrm{CC}$ & & 0.90 & 0.89 & 0.92 & 0.93 & 0.84 & 0.85 & 0.91 & 0.88 \\
\hline 4. & RSR & & 0.43 & 0.51 & 0.40 & 0.46 & 0.55 & 0.55 & 0.42 & 0.48 \\
\hline 5. & $\mathrm{~d}$ & & 0.94 & 0.93 & 0.95 & 0.94 & 0.88 & 0.86 & 0.91 & 0.90 \\
\hline
\end{tabular}

Note: Cal = calibration $;$ Val $=$ validation 
Table 7: Sub-watershed wise annual average water balance in the study area

\begin{tabular}{|c|c|c|c|c|c|c|}
\hline $\begin{array}{l}\text { Sub- } \\
\text { watershed }\end{array}$ & $\begin{array}{l}\text { Area } \\
\left(\mathbf{k m}^{2}\right)\end{array}$ & $\begin{array}{l}\text { Precipitation } \\
(\mathbf{m m})\end{array}$ & $\begin{array}{l}\text { Evapotranspiration } \\
(\mathrm{mm})\end{array}$ & $\begin{array}{l}\text { Surface run-off } \\
(\mathrm{mm})\end{array}$ & $\begin{array}{l}\text { Lateral Flow } \\
(\mathbf{m m})\end{array}$ & $\begin{array}{l}\text { Water Yield } \\
(\mathbf{m m})\end{array}$ \\
\hline SW-1 & 149.4 & 1214.6 & 746.8 & 348.0 & 0.3 & 453.7 \\
\hline SW-2 & 181.0 & 1312.9 & 754.9 & 341.3 & 0.3 & 541.9 \\
\hline SW-3 & 228.8 & 1323.4 & 757.3 & 541.0 & 0.4 & 772.1 \\
\hline SW-4 & 87.6 & 1420.2 & 736.6 & 449.8 & 0.2 & 667.5 \\
\hline SW-5 & 131.1 & 1492.0 & 751.1 & 543.9 & 0.5 & 719.8 \\
\hline SW-6 & 111.6 & 1496.0 & 791.4 & 523.4 & 0.2 & 778.4 \\
\hline SW-7 & 85.0 & 1396.0 & 857.0 & 560.1 & 0.3 & 750.7 \\
\hline SW-8 & 83.5 & 1256.9 & 797.0 & 456.7 & 0.1 & 570.7 \\
\hline SW-9 & 111.4 & 1102.5 & 785.7 & 477.6 & 0.4 & 566.9 \\
\hline SW-10 & 48.2 & 1311.1 & 783.7 & 479.6 & 0.2 & 570.8 \\
\hline SW-11 & 139.7 & 1598.7 & 744.9 & 528.3 & 0.7 & 775.7 \\
\hline SW-12 & 188.1 & 1356.8 & 758.7 & 360.5 & 0.4 & 510.6 \\
\hline SW-13 & 204.5 & 1456.9 & 772.8 & 459.4 & 0.3 & 696.1 \\
\hline SW-14 & 266.0 & 1594.5 & 749.7 & 412.9 & 1.1 & 768.2 \\
\hline SW-15 & 170.9 & 1205.7 & 788.8 & 371.7 & 0.3 & 560.6 \\
\hline SW-16 & 235.5 & 1307.7 & 792.2 & 381.7 & 0.2 & 501.8 \\
\hline SW-17 & 201.0 & 1256.4 & 792.8 & 361.4 & 0.3 & 510.8 \\
\hline SW-18 & 196.1 & 1610.7 & 692.7 & 321.1 & 0.6 & 594.4 \\
\hline SW-19 & 137.3 & 1609.7 & 711.3 & 465.7 & 0.8 & 674.1 \\
\hline SW-20 & 61.3 & 2072.3 & 717.4 & 1101.8 & 1.2 & 1269.7 \\
\hline SW-21 & 286.8 & 1783.7 & 785.4 & 528.5 & 0.7 & 804.5 \\
\hline SW-22 & 49.0 & 2186.5 & 717.7 & 1356.9 & 2.1 & 1481.4 \\
\hline SW-23 & 192.2 & 2051.7 & 659.3 & 875.0 & 1.4 & 1088.7 \\
\hline SW-24 & 209.7 & 1390.7 & 758.8 & 514.9 & 1.4 & 631.2 \\
\hline SW-25 & 127.9 & 2071.9 & 662.4 & 925.8 & 1.1 & 1196.3 \\
\hline SW-26 & 194.7 & 1381.4 & 808.5 & 443.8 & 0.9 & 574.7 \\
\hline SW-27 & 196.2 & 2251.4 & 678.8 & 1371.9 & 2.4 & 1428.8 \\
\hline SW-28 & 189.0 & 2217.6 & 712.6 & 1403.7 & 2.3 & 1485.9 \\
\hline SW-29 & 143.1 & 2116.5 & 670.0 & 1441.2 & 3.0 & 1582.3 \\
\hline SW-30 & 174.2 & 2209.2 & 721.8 & 1350.7 & 3.6 & 1560.3 \\
\hline SW-31 & 311.4 & 2108.7 & 703.0 & 1339.7 & 3.7 & 1488.2 \\
\hline $\begin{array}{l}\text { Watershed, } \\
\text { as a whole }\end{array}$ & 5092.0 & 1618.2 & 747.1 & 678.6 & 1.0 & 857.3 \\
\hline
\end{tabular}

17

18

19

20 
Table 8: Monthly break up of average annual water balance

\begin{tabular}{llllll}
\hline Month & $\begin{array}{l}\text { Precipitation } \\
(\mathbf{m m})\end{array}$ & $\begin{array}{l}\text { Evapotranspiration } \\
(\mathbf{m m})\end{array}$ & $\begin{array}{l}\text { Surface run-off } \\
(\mathbf{m m})\end{array}$ & $\begin{array}{l}\text { Water Yield } \\
(\mathbf{m m})\end{array}$ & $\begin{array}{l}\text { Lateral Flow } \\
(\mathbf{m m})\end{array}$ \\
\hline Jan & 4.2 & 9.5 & 0.9 & 9.3 & 0.0 \\
Feb & 2.9 & 21.4 & 0.5 & 6.8 & 0.0 \\
Mar & 11.1 & 79.0 & 0.2 & 6.3 & 0.0 \\
Apr & 36.2 & 117.3 & 2.8 & 7.2 & 0.0 \\
May & 60.3 & 68.1 & 8.3 & 17.3 & 0.0 \\
Jun & 323.9 & 77.9 & 149.8 & 170.1 & 0.1 \\
Jul & 476.6 & 86.6 & 198.2 & 226.0 & 0.1 \\
Aug & 346.1 & 96.9 & 162.2 & 180.4 & 0.2 \\
Sep & 189.8 & 70.8 & 89.2 & 96.4 & 0.2 \\
Oct & 131.1 & 67.4 & 53.0 & 58.8 & 0.2 \\
Nov & 32.0 & 41.2 & 12.7 & 43.6 & 0.1 \\
Dec & 2.9 & 12.4 & 1.3 & 38.1 & 0.1 \\
\hline Annual & 1616.9 & 748.4 & 679.0 & 860.2 & 1.0 \\
\hline
\end{tabular}


38 Table 9: Average annual sediment yield during the years of identifying critical sub-watersheds

\begin{tabular}{|c|c|c|c|c|c|c|c|c|c|c|c|c|c|}
\hline \multirow{2}{*}{$\begin{array}{l}\text { Sub- } \\
\text { watershed } \\
\text { number }\end{array}$} & \multirow{2}{*}{ Area (ha) } & \multicolumn{10}{|c|}{ Sediment yield $\left(\mathrm{t} \mathrm{ha}^{-1}\right)$} & \multirow{2}{*}{$\begin{array}{l}\text { Average } \\
\text { sediment } \\
\text { yield } \\
\left(\mathrm{t} \mathrm{ha}^{-1}\right)\end{array}$} & \multirow{2}{*}{$\begin{array}{l}\text { Priority } \\
\text { rank }\end{array}$} \\
\hline & & 1999 & 2000 & 2001 & 2002 & 2003 & 2004 & 2008 & 2009 & 2010 & 2011 & & \\
\hline SW-1 & 14935.7 & 0.0 & 0.0 & 0.0 & 0.0 & 0.0 & 0.0 & 0.0 & 0.0 & 0.0 & 0.1 & 0.0 & 23 \\
\hline SW-2 & 18100.5 & 0.0 & 0.0 & 0.0 & 0.0 & 0.0 & 0.0 & 0.0 & 0.0 & 0.0 & 0.0 & 0.0 & 23 \\
\hline SW-3 & 22878.6 & 21.7 & 19.1 & 12.0 & 1.1 & 0.9 & 5.9 & 16.2 & 19.5 & 3.2 & 55.6 & 15.5 & 11 \\
\hline SW-4 & 8762.2 & 0.0 & 0.0 & 0.0 & 0.0 & 0.0 & 0.0 & 0.0 & 0.0 & 0.0 & 0.0 & 0.0 & 23 \\
\hline SW-5 & 13107.6 & 0.0 & 0.0 & 0.0 & 0.0 & 0.0 & 0.0 & 0.7 & 4.1 & 0.0 & 0.0 & 0.5 & 18 \\
\hline SW-6 & 11154.6 & 44.5 & 39.2 & 24.6 & 2.3 & 1.7 & 12.1 & 32.1 & 32.3 & 6.5 & 114.3 & 31.0 & 5 \\
\hline SW-7 & 8498.0 & 58.4 & 51.4 & 32.3 & 3.0 & 2.3 & 15.9 & 42.6 & 45.2 & 8.6 & 149.9 & 41.0 & 4 \\
\hline SW-8 & 8350.4 & 60.0 & 48.9 & 32.9 & 3.0 & 2.3 & 16.1 & 39.9 & 34.7 & 8.6 & 189.9 & 43.6 & 3 \\
\hline SW-9 & 11143.7 & 0.0 & 0.0 & 0.0 & 0.0 & 0.0 & 0.0 & 0.0 & 0.0 & 0.0 & 0.0 & 0.0 & 23 \\
\hline SW-10 & 4824.3 & 0.1 & 0.1 & 0.0 & 0.0 & 0.0 & 0.0 & 0.0 & 0.1 & 0.1 & 0.0 & 0.1 & 20 \\
\hline SW-11 & 13969.7 & 0.1 & 0.1 & 0.0 & 0.0 & 0.0 & 0.0 & 0.0 & 0.1 & 0.0 & 0.0 & 0.0 & 22 \\
\hline SW-12 & 18804.8 & 0.3 & 0.1 & 0.0 & 0.0 & 0.0 & 0.0 & 0.0 & 0.1 & 0.0 & 0.0 & 0.1 & 20 \\
\hline SW-13 & 20449.3 & 24.3 & 19.9 & 13.4 & 1.2 & 0.9 & 6.6 & 16.3 & 14.1 & 3.5 & 77.5 & 17.8 & 9 \\
\hline SW-14 & 26596.8 & 0.1 & 0.0 & 0.0 & 0.0 & 0.0 & 0.0 & 0.0 & 0.0 & 0.0 & 0.0 & 0.0 & 22 \\
\hline SW-15 & 17089.1 & 0.0 & 0.0 & 0.0 & 0.0 & 0.0 & 0.0 & 0.0 & 0.0 & 0.0 & 0.0 & 0.0 & 22 \\
\hline SW-16 & 23546.9 & 0.0 & 0.0 & 0.0 & 0.0 & 0.0 & 0.0 & 0.0 & 0.0 & 0.0 & 0.0 & 0.0 & 23 \\
\hline SW-17 & 20102.9 & 24.7 & 20.2 & 13.6 & 1.2 & 1.0 & 6.7 & 16.6 & 14.4 & 3.5 & 99.5 & 20.1 & 8 \\
\hline SW-18 & 19611.5 & 25.3 & 20.7 & 14.0 & 1.3 & 1.0 & 6.9 & 17.0 & 14.6 & 3.6 & 102.0 & 20.6 & 7 \\
\hline SW-19 & 13733.2 & 0.3 & 0.1 & 0.0 & 0.0 & 0.0 & 0.0 & 0.0 & 0.2 & 0.0 & 0.0 & 0.1 & 19 \\
\hline SW-20 & 6129.1 & 68.3 & 62.8 & 42.5 & 3.5 & 2.4 & 19.6 & 53.4 & 40.8 & 9.8 & 261.5 & 56.5 & 2 \\
\hline SW-21 & 28682.3 & 0.0 & 0.0 & 0.0 & 0.0 & 0.0 & 0.0 & 0.0 & 0.1 & 0.0 & 0.0 & 0.0 & 23 \\
\hline SW-22 & 4896.4 & 84.0 & 77.7 & 53.2 & 4.3 & 3.0 & 24.4 & 66.7 & 49.5 & 12.0 & 323.5 & 69.8 & 1 \\
\hline SW-23 & 19218.3 & 1.3 & 1.0 & 0.0 & 0.0 & 0.0 & 0.0 & 0.1 & 0.8 & 0.1 & 2.9 & 0.6 & 17 \\
\hline SW-24 & 20965.0 & 3.7 & 1.0 & 0.6 & 0.2 & 0.2 & 0.7 & 0.2 & 1.7 & 0.5 & 18.9 & 2.8 & 16 \\
\hline SW-25 & 12789.0 & 29.9 & 28.0 & 20.4 & 1.6 & 1.1 & 9.3 & 25.4 & 17.6 & 4.4 & 118.7 & 25.6 & 6 \\
\hline SW-26 & 19471.5 & 0.0 & 0.0 & 0.0 & 0.0 & 0.0 & 0.0 & 0.1 & 0.2 & 0.1 & 0.0 & 0.0 & 21 \\
\hline SW-27 & 19623.3 & 18.5 & 17.4 & 13.3 & 1.0 & 0.7 & 6.0 & 16.5 & 10.7 & 2.7 & 74.9 & 16.2 & 10 \\
\hline SW-28 & 18897.1 & 3.7 & 1.1 & 0.7 & 0.2 & 0.1 & 0.8 & 0.2 & 1.4 & 0.4 & 21.0 & 3.0 & 15 \\
\hline SW-29 & 14309.3 & 7.3 & 2.7 & 1.3 & 0.4 & 0.3 & 1.9 & 0.3 & 2.9 & 1.1 & 31.7 & 5.0 & 12 \\
\hline SW-30 & 17419.5 & 4.5 & 1.5 & 0.9 & 0.2 & 0.1 & 1.0 & 0.2 & 1.6 & 0.5 & 20.5 & 3.1 & 14 \\
\hline SW-31 & 31135.1 & 5.8 & 2.0 & 1.3 & 0.3 & 0.2 & 1.5 & 0.4 & 2.2 & 0.7 & 27.9 & 4.2 & 13 \\
\hline
\end{tabular}


Table 10: Area under different soil erosion classes in the Marol watershed

\begin{tabular}{lllll}
\hline $\begin{array}{l}\text { Sr. } \\
\text { No. }\end{array}$ & $\begin{array}{l}\text { Sediment Yield } \\
\left(\mathbf{t} \cdot \mathbf{h a}^{-\mathbf{1}} \mathbf{y r}^{-1}\right)\end{array}$ & Sub-watershed & Percent Area & $\begin{array}{l}\text { Soil Erosion } \\
\text { Class }\end{array}$ \\
\hline 1. & $0-5$ & $\begin{array}{l}1,2,4,5,9,10,11,12, \\
14,15,16,19,21,23,24,26,\end{array}$ & 69.7 & Slight \\
& & $28,29,30,31$ & & Moderate \\
2. & $5-10$ & --- & 0.0 & High \\
3. & $10-20$ & $3,13,27$ & 12.4 & Very high \\
4. & $20-40$ & $6,17,18,25$ & 12.5 & Severe \\
5. & $40-80$ & $7,8,20,22$ & 5.5 & Very severe \\
6. & $>80$ & --- & 0.0 & \\
\hline
\end{tabular}




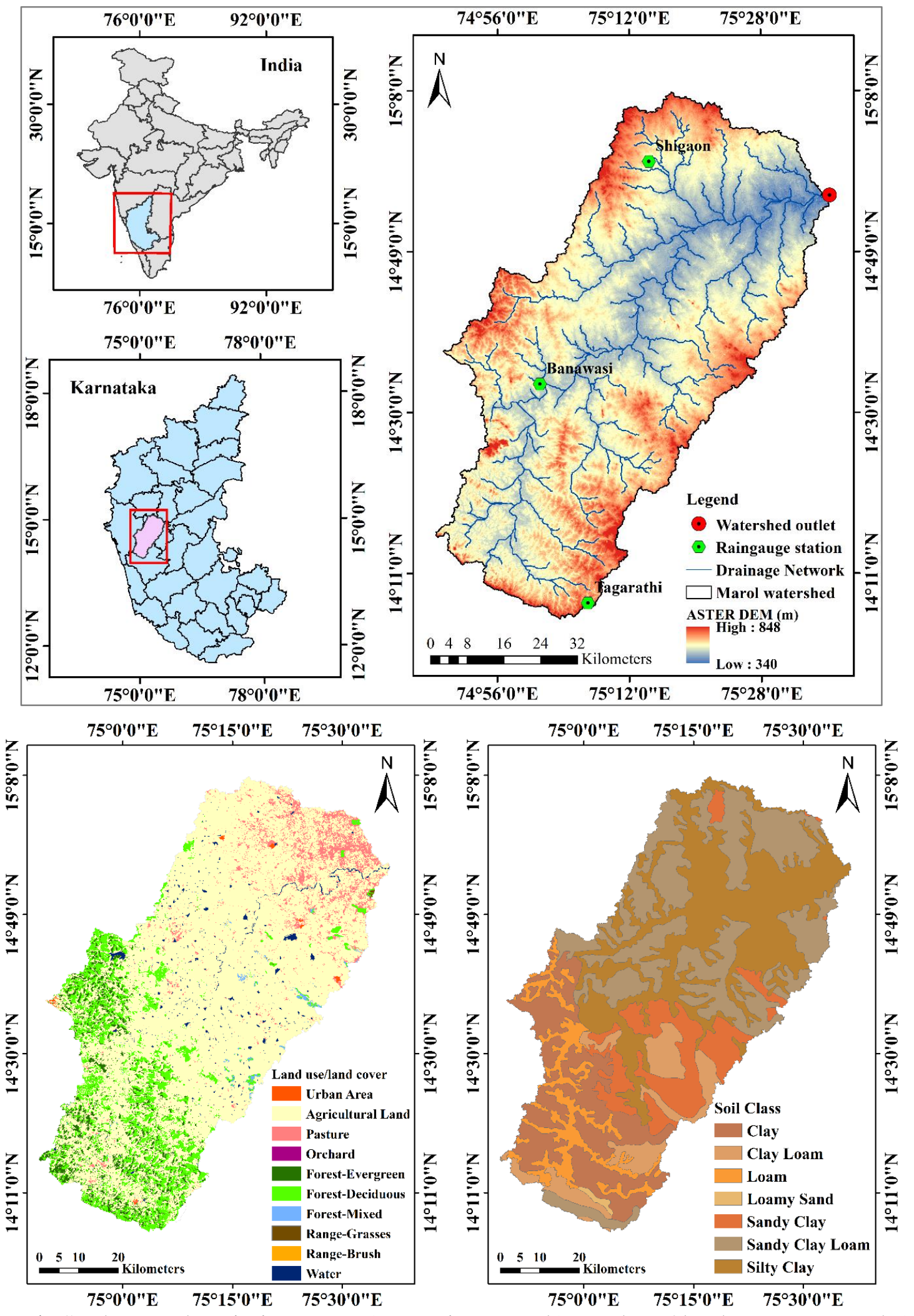

60 Figure 1: Study area description maps a) Location map, b) Land use/ land cover map and c) Soil 


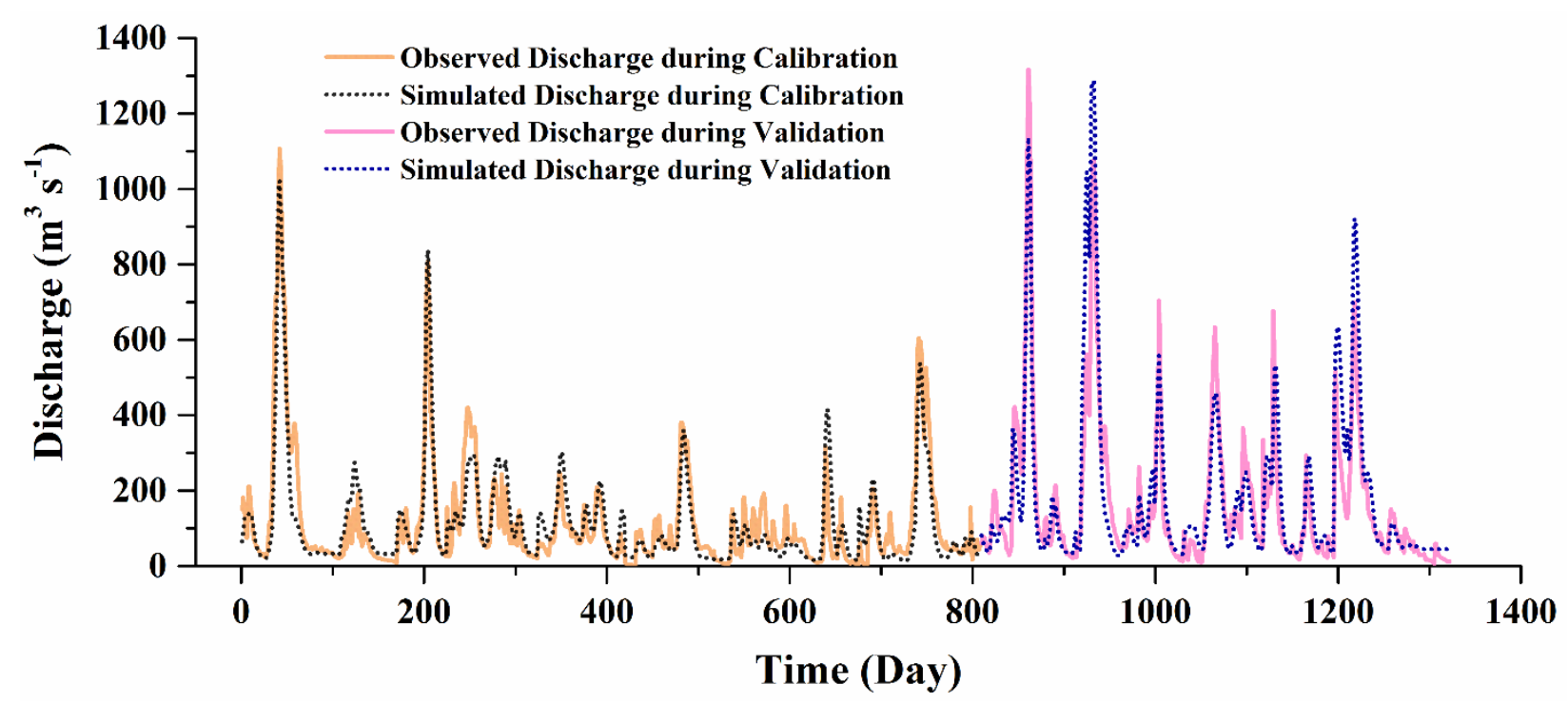

Figure 2: Comparison of the observed and SWAT simulated discharge for daily calibration

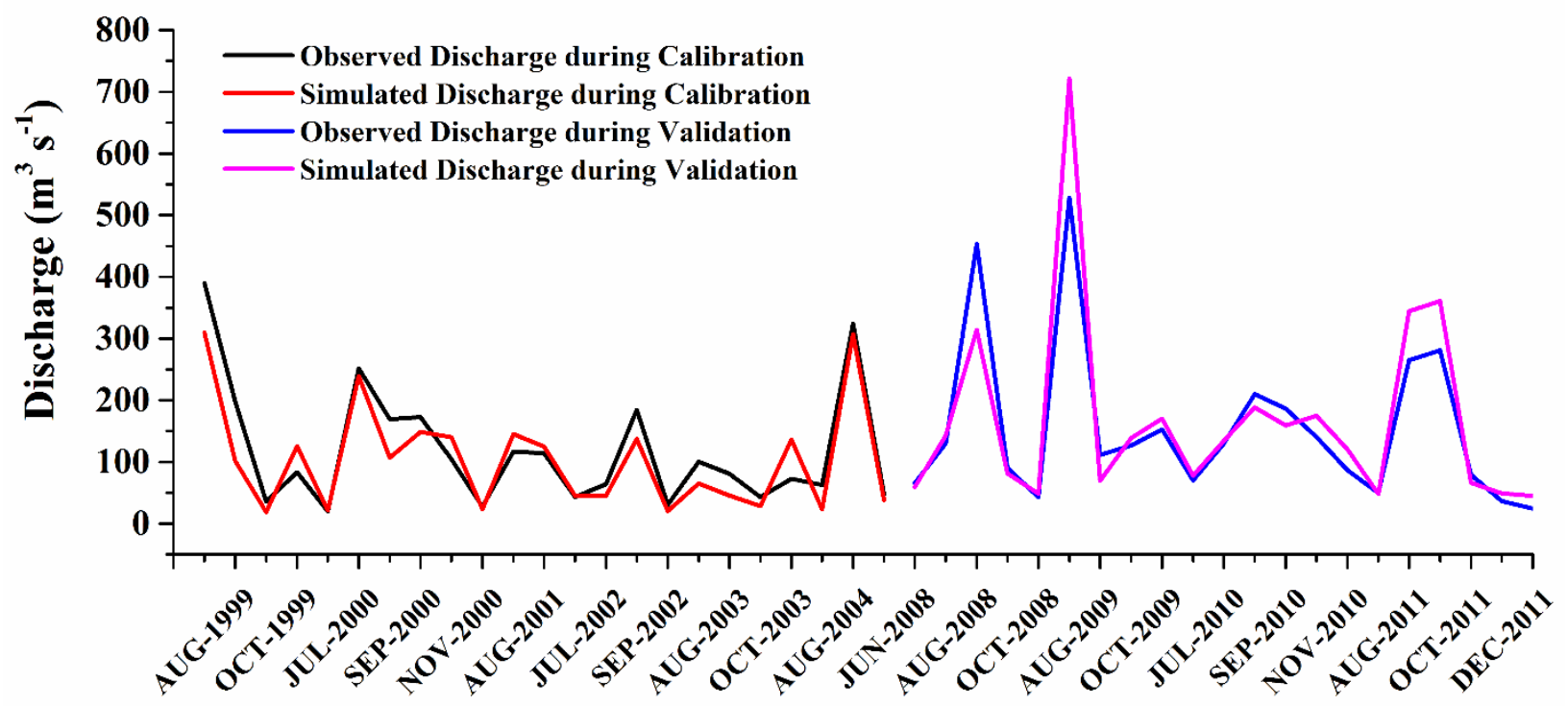

Time (Month)

67 Figure 3: Comparison of the observed and SWAT simulated discharge for monthly calibration 


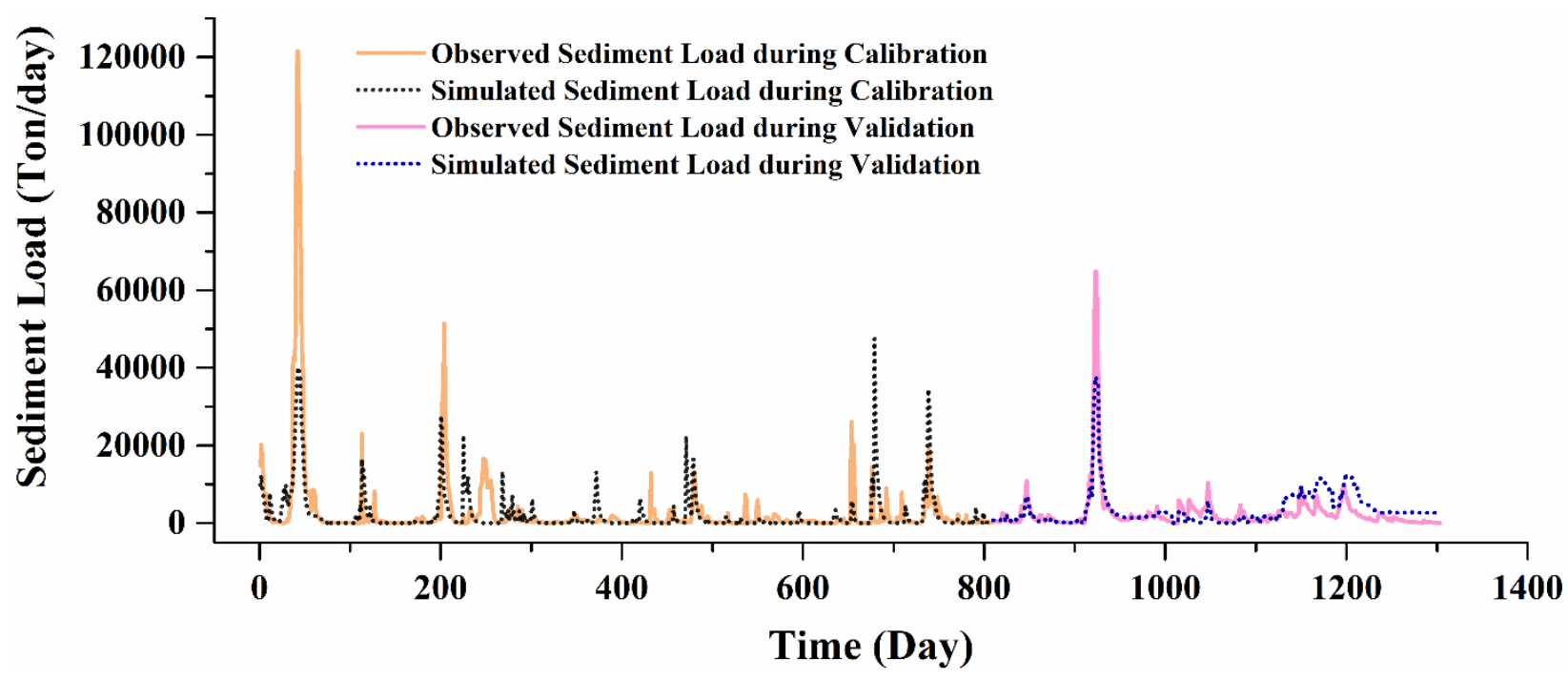

72 Figure 4: Comparison of the observed and SWAT simulated sediment load for daily calibration (1999-2004) and validation (2008-2011) at the watershed outlet

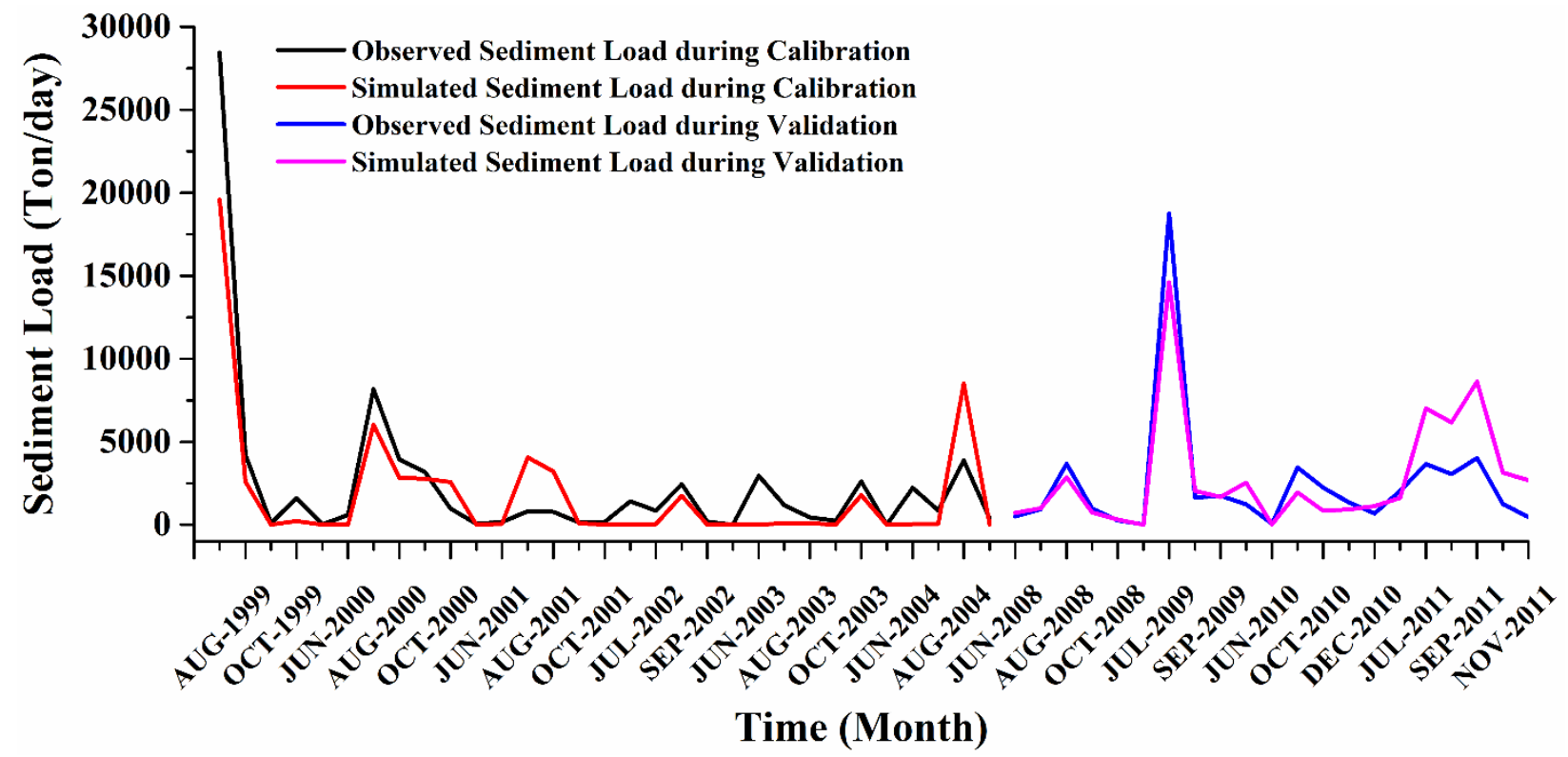

Figure 5: Comparison of the observed and SWAT simulated sediment load for monthly calibration (1999-2004) and validation (2008-2011) at the watershed outlet 

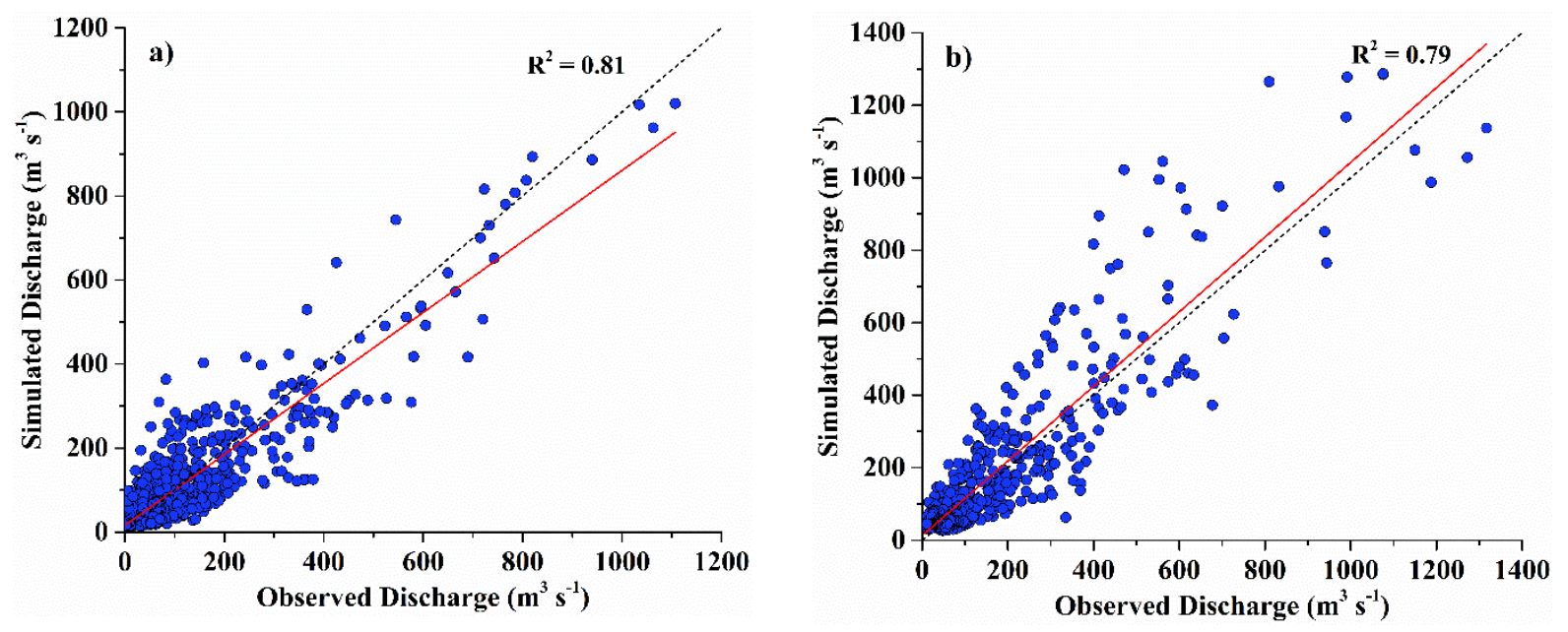

Figure 6: Observed versus simulated discharge for daily a) calibration and b) validation
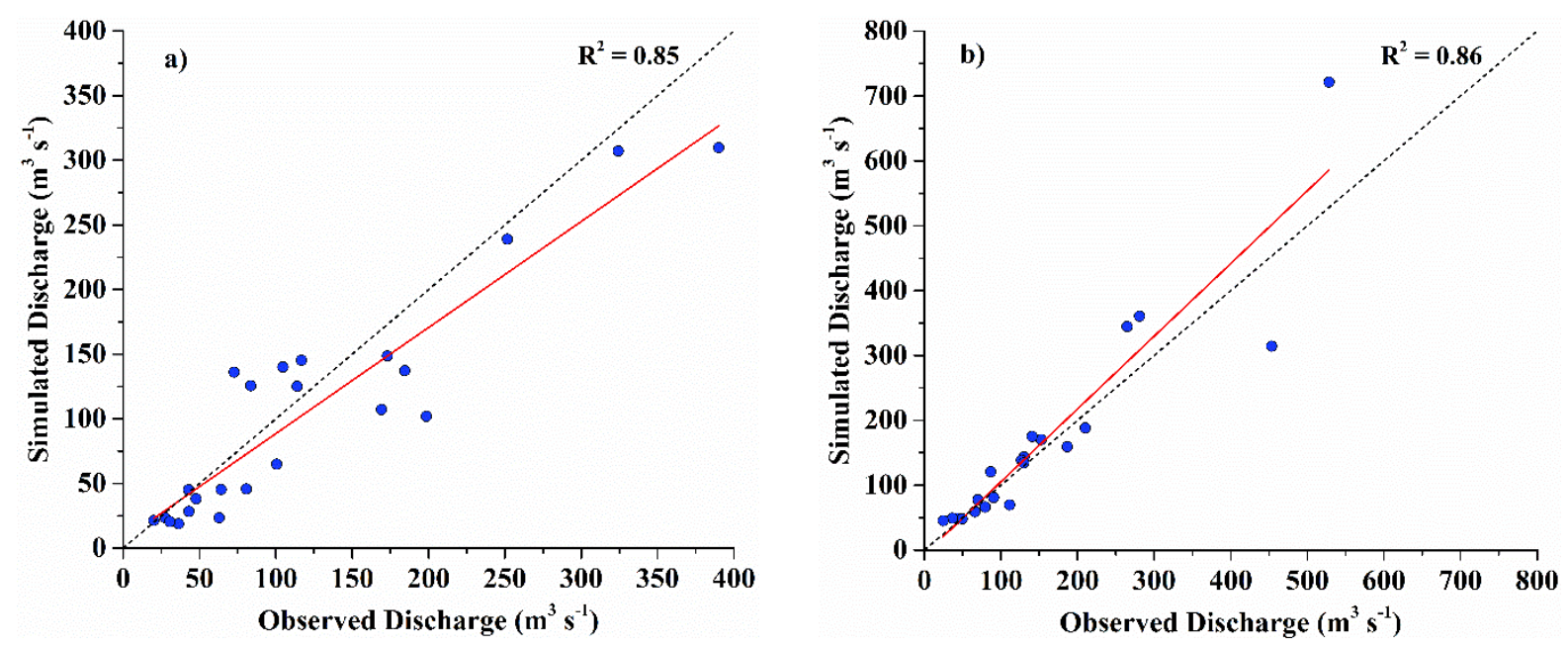

$80 \quad$ Figure 7: Observed versus simulated discharge for monthly a) calibration and b) validation

81

82

83

84 

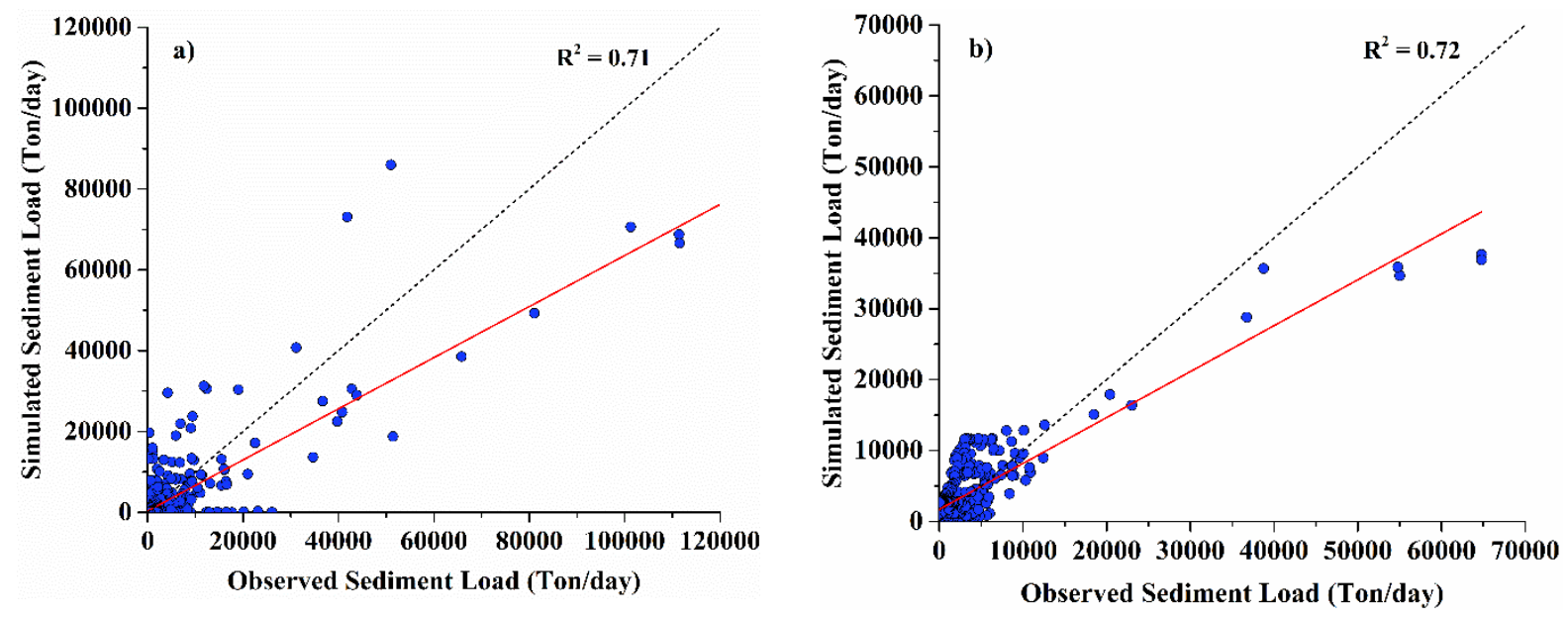

Figure 8: Observed versus simulated sediment load for daily a) calibration and b) validation
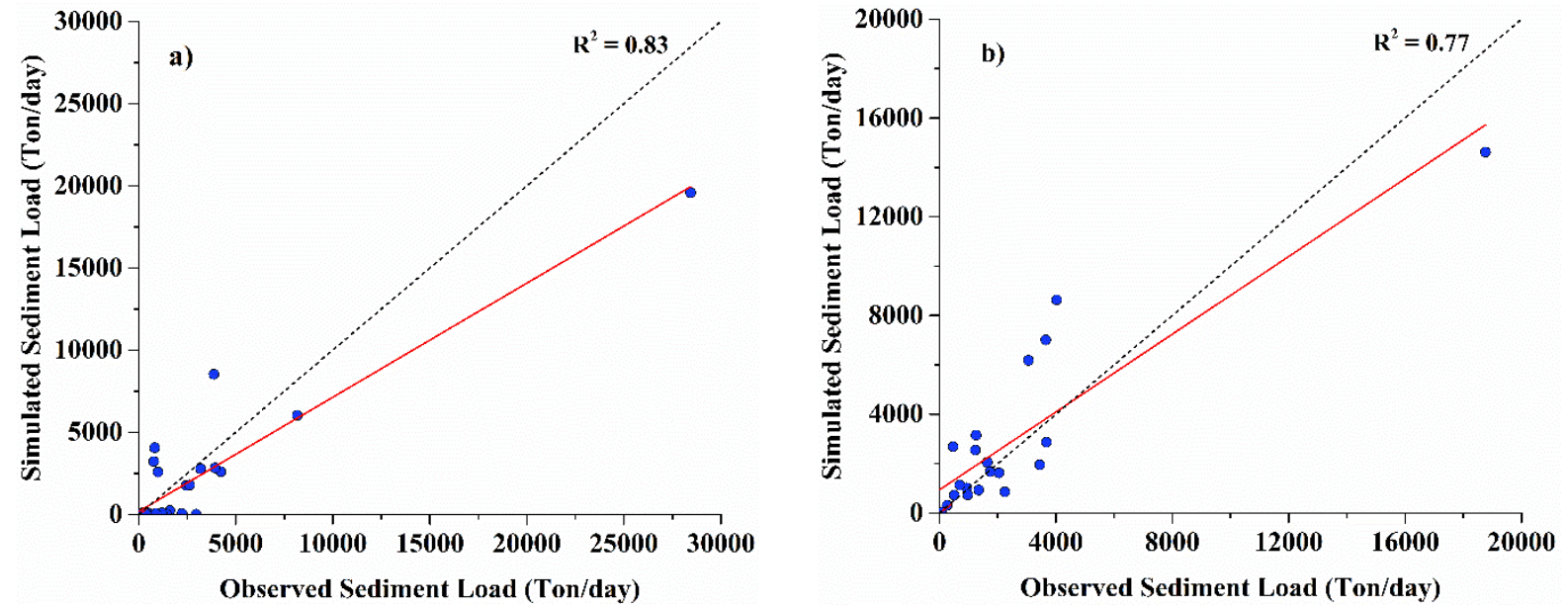

86 Figure 9: Observed versus simulated sediment load for monthly a) calibration and b) validation

87

88

89

90 


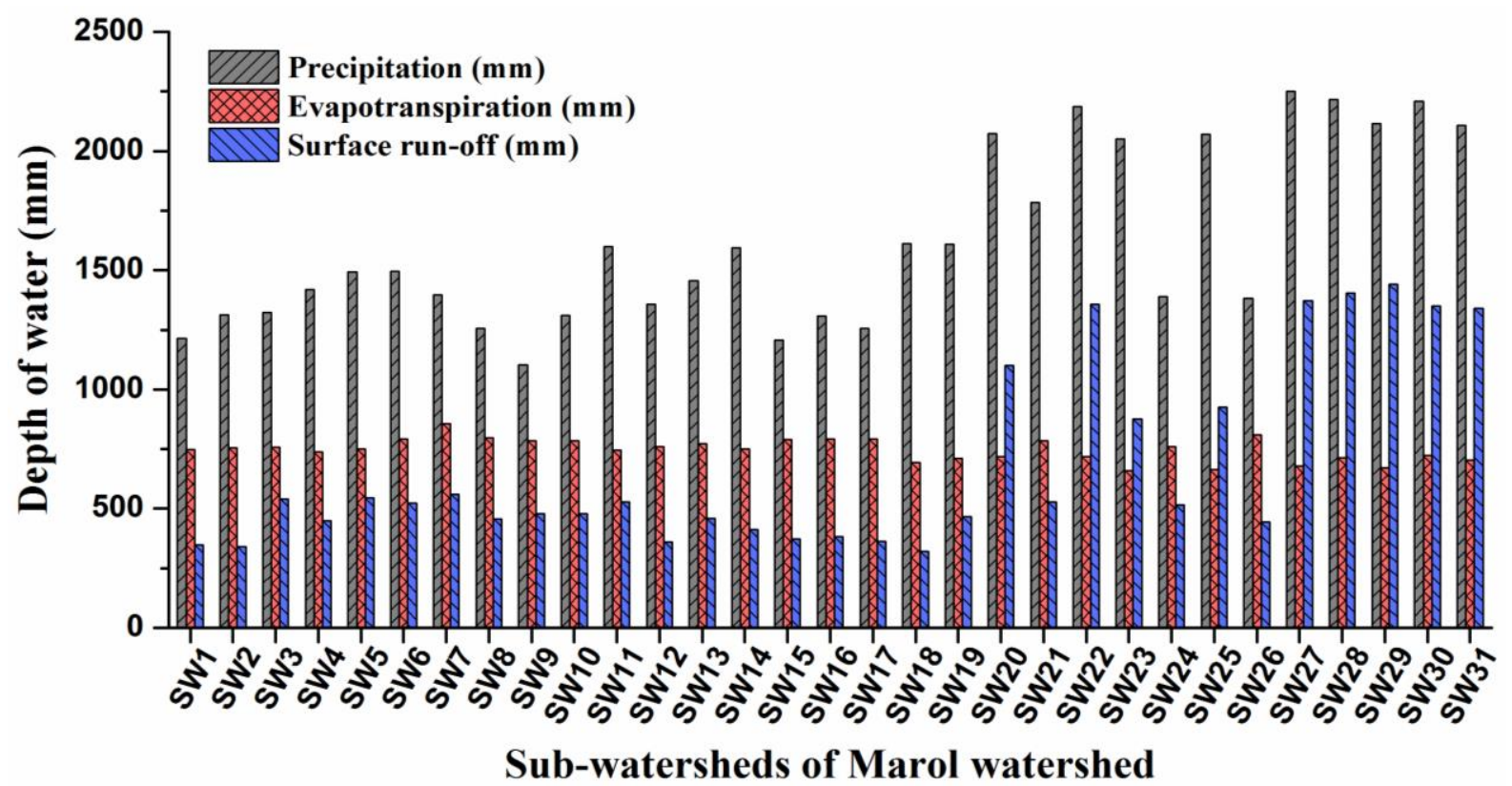

Figure 10: Sub-watershed wise annual average water balance components

93

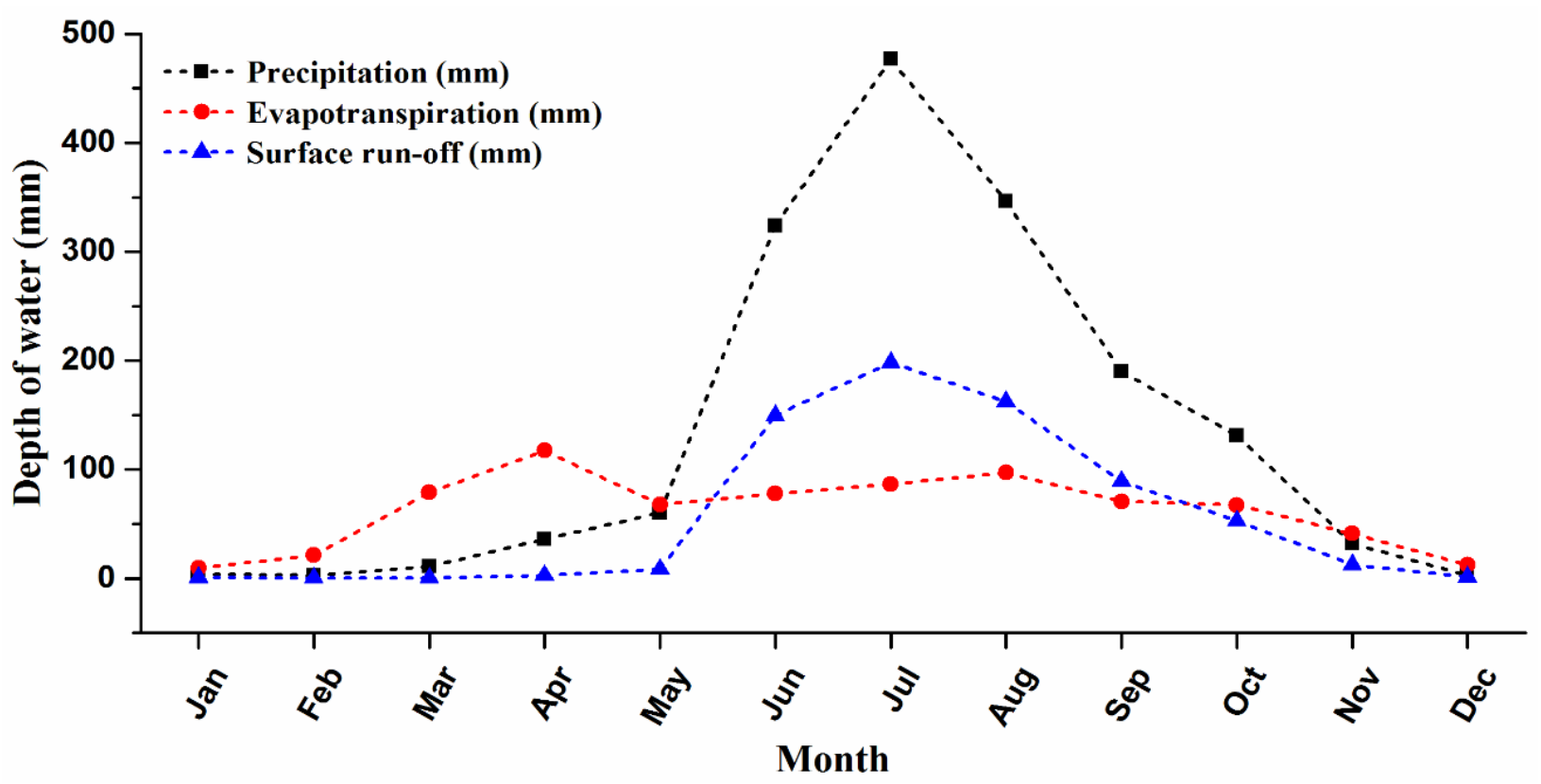

Figure 11: Monthly average values of water balance components 


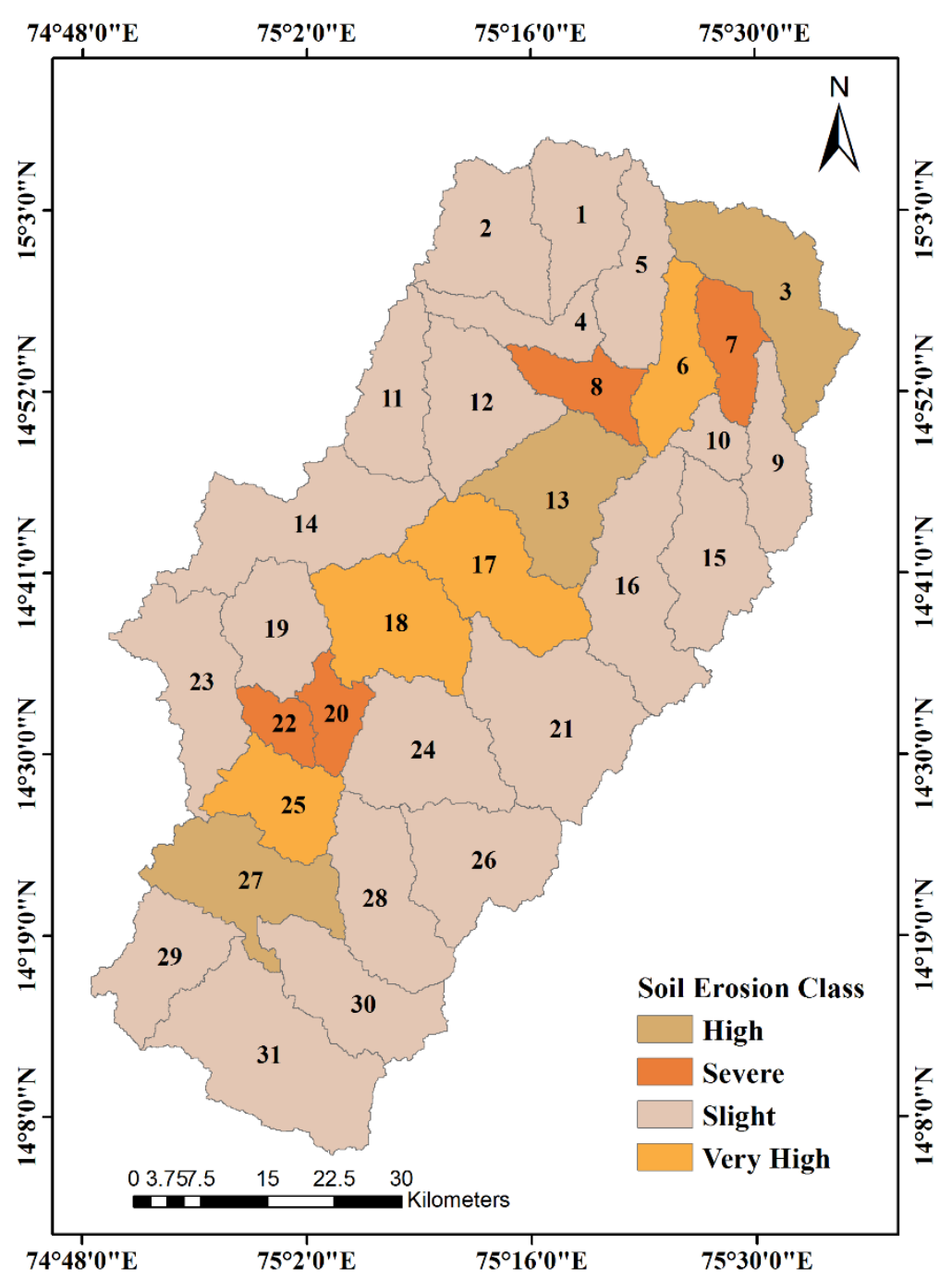




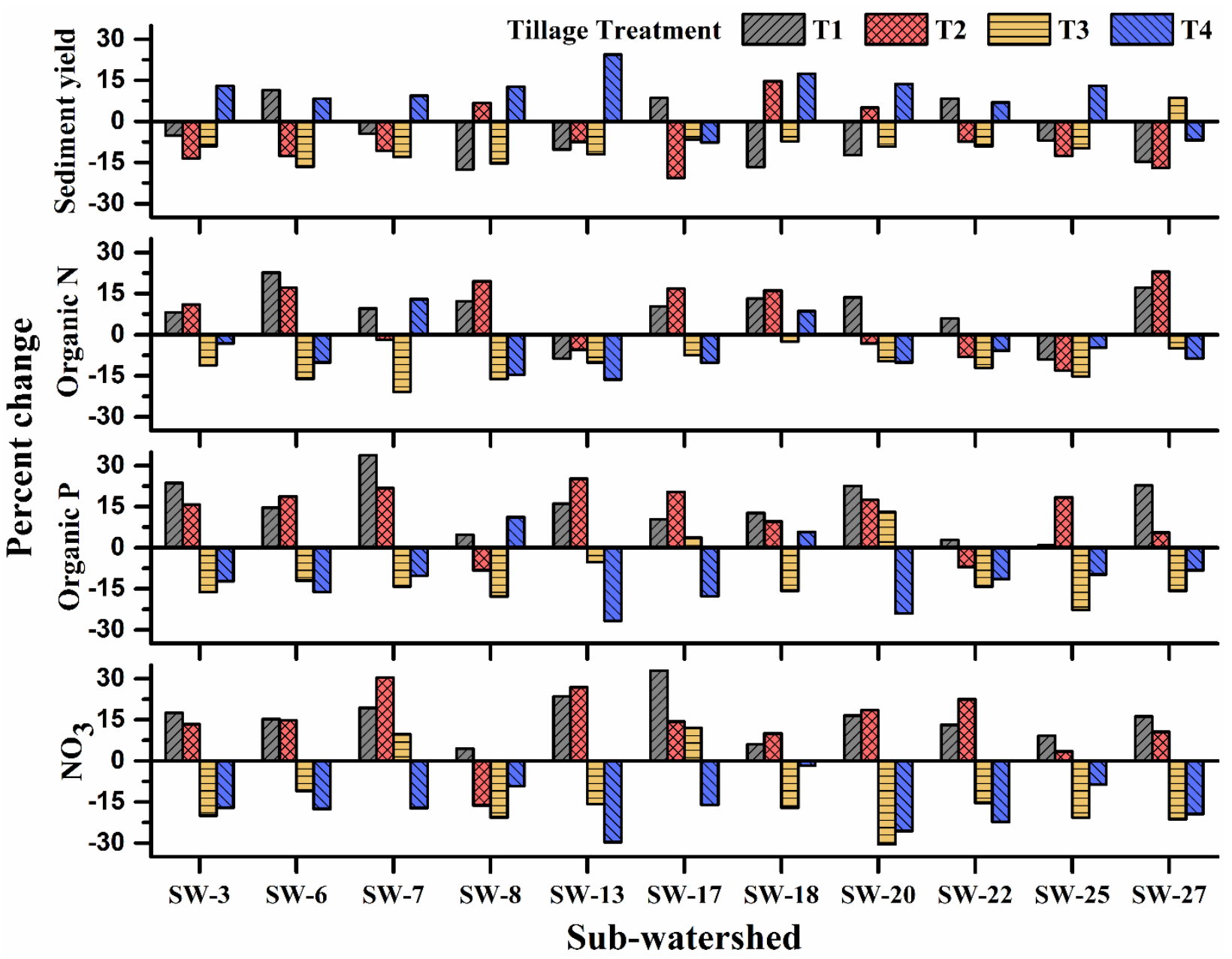

Figure 13: Percent change in simulated sediment and nutrients after implementing alternate

113 tillage treatments (T1: zero tillage; T2: conservation tillage; T3: field cultivator; T4: mould board plough) as compared to conventional tillage treatment (country plough) 

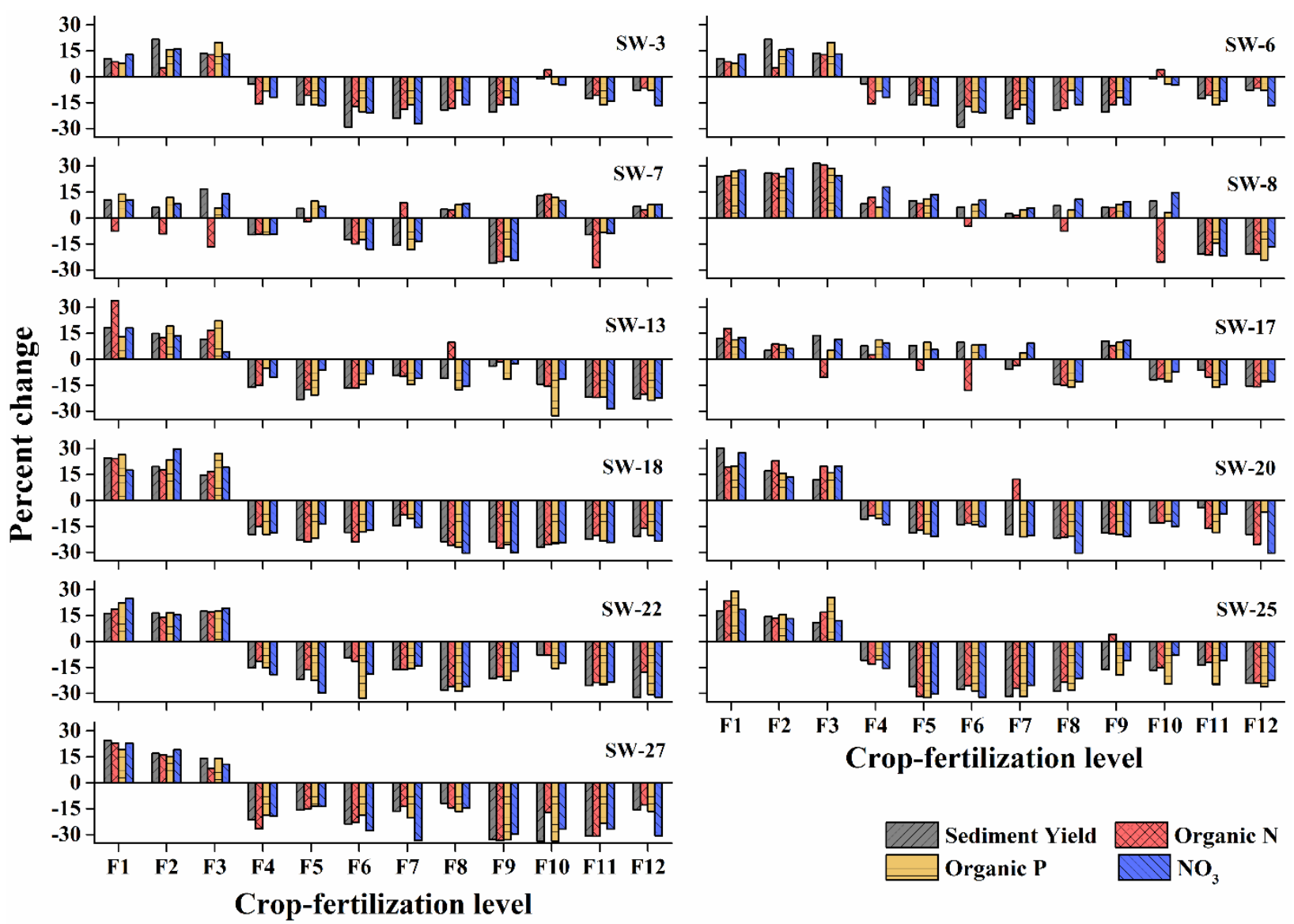

Figure 14: Percent change in simulated sediment and nutrients after implementing different crop124 fertilization treatments in the critical sub-watersheds as compared to rice cultivation with existing practice of fertilization 

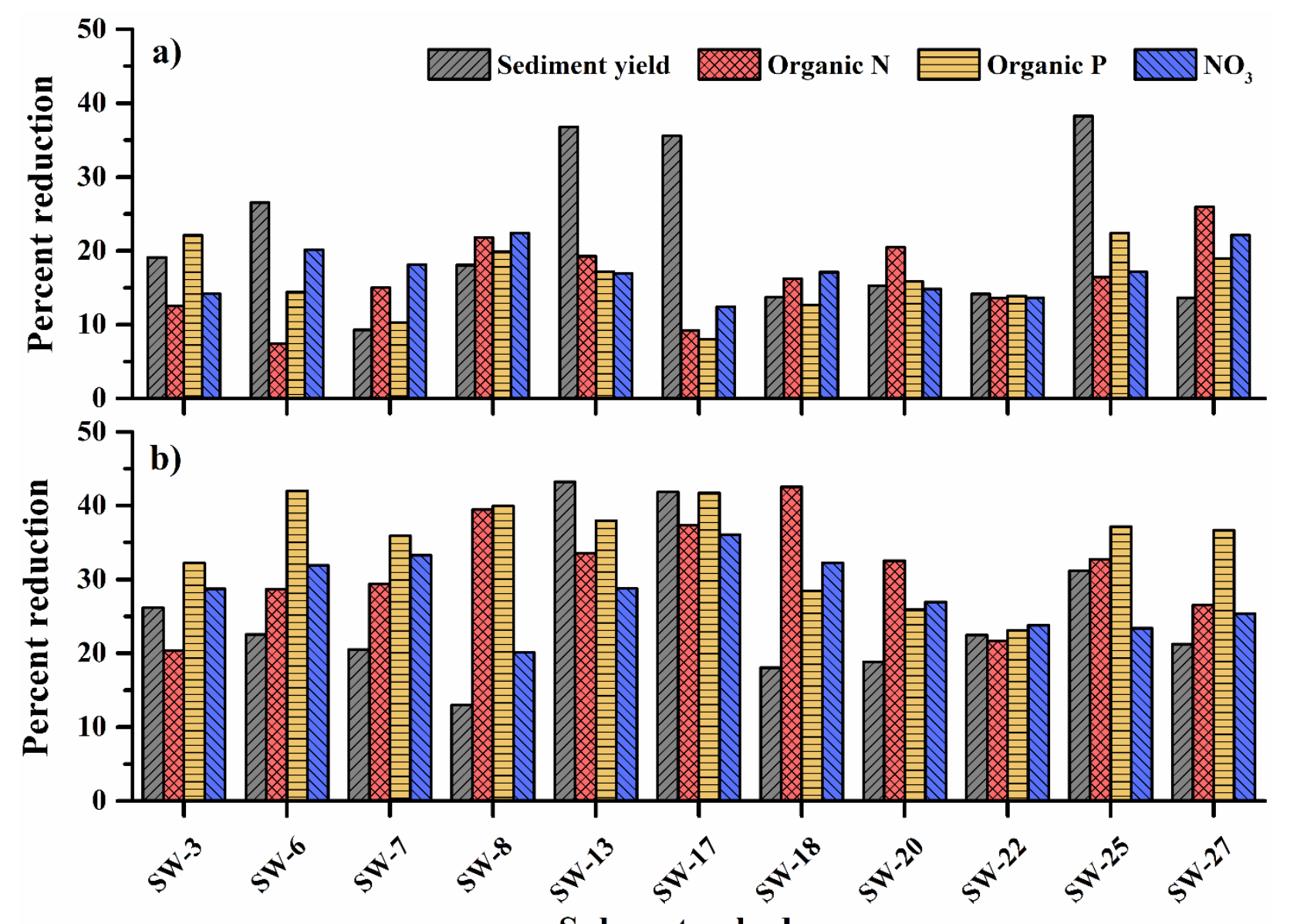
watersheds 